Portland State University

PDXScholar

1973

\title{
Thomas Hardy : a Study; Suffering, Human Will, and Grace in the Major Novels
}

Russell E. Borland

Portland State University

Follow this and additional works at: https://pdxscholar.library.pdx.edu/open_access_etds

Part of the English Language and Literature Commons

Let us know how access to this document benefits you.

\section{Recommended Citation}

Borland, Russell E., "Thomas Hardy : a Study; Suffering, Human Will, and Grace in the Major Novels" (1973). Dissertations and Theses. Paper 2029.

https://doi.org/10.15760/etd.2027

This Thesis is brought to you for free and open access. It has been accepted for inclusion in Dissertations and Theses by an authorized administrator of PDXScholar. Please contact us if we can make this document more accessible: pdxscholar@pdx.edu. 
AN ABSTRACT OF THE THESIS OF Russell E. Borland for the Master of Ants in Finglish presented Jufy 23, 1973.

Title: Thomas Hardy: A Study: Suffering, Human WIII, and Grace in the Major Novels.

APPRONED BY MEUBERS OF THE THESIS COMIITEE:
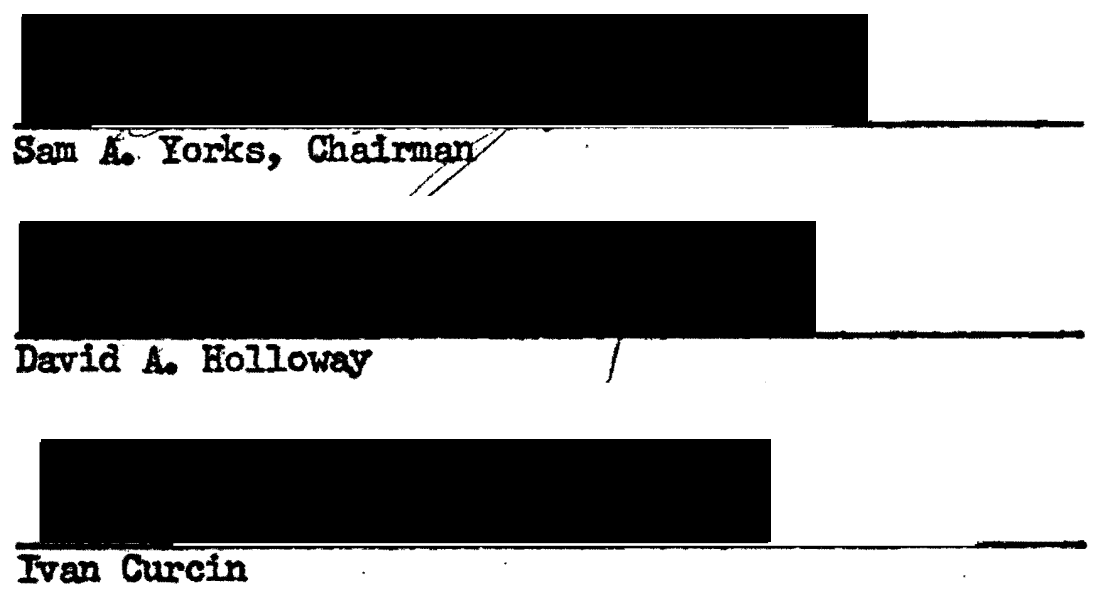

This thesis concentrates on human relations and the potential for man's beatitude in Hardy's major novels through an exploration of sufPering, human will, evolutionary meliorism, and Grace, discussed in separate chapters. Chapter I is devoted to an introduction of the major elements of what is here called Hardy's vision. Relying Iargely on Florence Emily Hardy's The Life of Thomas Hardy and on references to some of the novels, a compilation of impressions is arranged into what seems to represent accurately the basic nature of the world and human relations in Hardy's novels. The emphasis and the thrust of the vision are the ways in which human doings interrelate. 
Chapter II explores suffering largely in terms of its causes. Through descriptions of individual characters and their relations with other characters, the principal shortcomings of man in his human doings are categorized into two rather basic expressions of human will, selfassertion and self-restraint. It is the extremes of self-assertion, enacted through extreme passions or extreme intellectuality, and the extremes of self-restraint, expressed through passive acquiescence and social imitation, which are demonstrated as the major causes of suffering in human relations.

The use of suffering for influencing the humen will is the thrust of Chapter III. After reviewing some critical views of the potential of the human will to affect the human condition in Hardy's novels, examples from the novels of the ways in which suffering influenced dectsions and actions are discussed. An awareness of suffering and the consequent sympathy are evinced as bases: for actions and decistons which work to lighten some of the suffering or possible suffering of ather characters.

Chapter IV concentrates on Hardy's concept of evolutionary meliom rigm, Using T. H. Huxley's comments as a background definition of evolution, it is seen that the ethically better characters tend to survive and to replace characters with non-adaptive, non-ethical tendencles. Hardy's novels tend towards evolving an amelioration of man's condition. An investigation of the characters and of the narrative point of view reveals some bases for sadness and sympathy for all of the characters, making Hardy's View of evolutionary meliorism different from Huxiey's view of evolution in human soclety in that Huxiey 
emphasizes imftation while Hardy seems to emphasize varlety as a necessary adjunct to evolutionary mellorism.

1 discussion of the 01d Testament concept of Grace as analogous to what seems to be Hardy's hope for man is the topic of Chapter V. Loving-kindness as the motive of human will in actions and decisions is seen as the result of man evolving a more intense consclousness of the caluses of human siffering. As man may evolve an instinctual will to act through loving-kindness, so may the Universal Will through its interrelation with man's will, based on connections discussed in Chapter I, also develop a consctousness, sympathy, and a new concept of Grace in which a conscious, sympathetio Universal Will urges, hopofully mercifuliy, the processes of the universe in place of the biblical concept of God's Grace.

The concluding chepter summarizes the major emphases of the preceding chapters into a discussion of the moral importance of the use of human will for alleviating as much suffering as possible in human IIres and society. The pains and the potential of human Iife which - Hardy demonstrates in the novels becomes the basis for using the worst consequences and possibie consequences to motivate mankind to attempt to afford every man as much rellef from suffering as possible. 
TO THE OFFICE OF GRADUATE STUDIES AND RESEARCH:

The members of the Committee approve the thesis of

Russell E. Borland presented July 23, 1973.

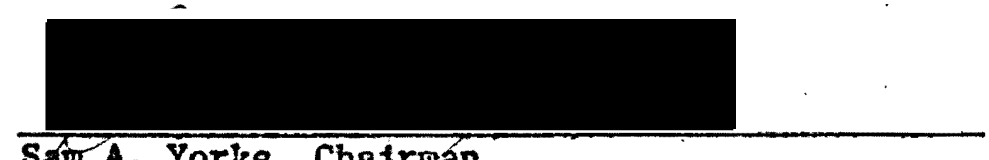

Sain A. Yorles, Chatrman

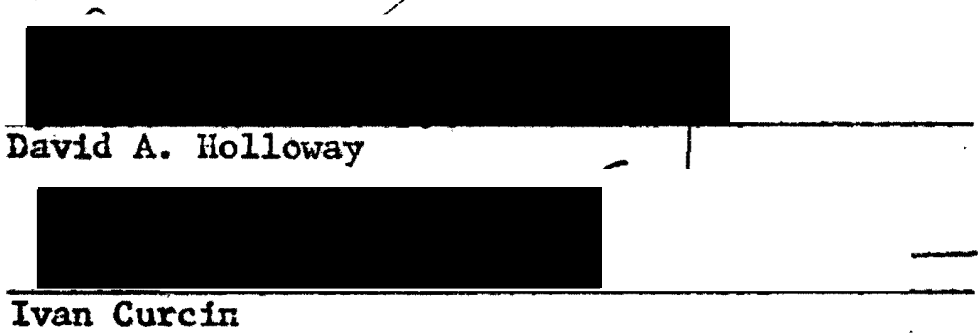

APPROVED:

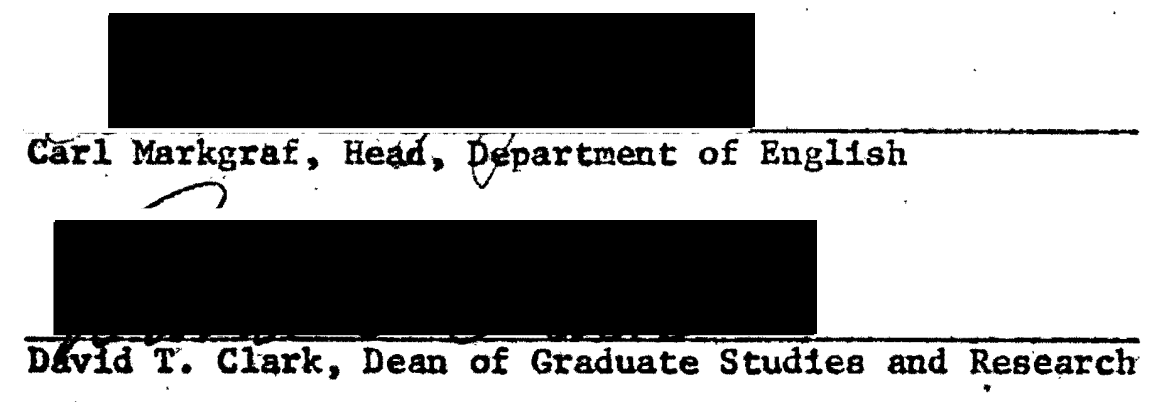

July 25, 1973 
THOMAS HARDY: A SPUDY

SUEFERIIG, HUMAN WIIT, AND GRACE

IN THE MAJOR NOVERS

\author{
bo \\ FIISSFT. E. BORLAND
}

A thesis submitted in partial fulficiment of the

requirements for the degree of

\title{
MASTER OF ARISS
}

in

EAICISE:

Portiland State University

1973 


\section{PREFACE}

This study was engendered out of a response to Thomas Hardy's Plction which parallels Wilson and Helen Thomas Follett's observation that Fardy's Idylilc novels "are marked by a sense of the insubstantial character of the walI that shuts men and wemen out of their beatitude. nt It secmed that not only the "Idyli10" novels, but the later, "darker" novals shared a sense of the possibility of man's beatitude; that is, the possibility of Ilfe with happiness and littie or no suffering. A roong choice hastily made, the pressures of jealousy and the desire to: possess, the overriding guidance of emotion seemed rather often to be the causes of fallure and of suffering.

Lt IIrst, it seemed too easy to categorize Hardy's characters Into "good or "bad" types; and if there seemed to be a larger proportion of "bad" characters than in the novels of Dickens' time, it seemed only a natural and realistic extension of the world of the novel in its depiction of uife." If characters Iike Sergeant Troy, Felice Charmond, Alec DiUrbervilie; or Arabelia Donn could be classified as finally too impulsively "bad" and as almost tholly responsible for a series of events which brought suffering to others, the response became complicated when faced with characters Iike Michaol Henchard and Hustacia Vye. Bach of these characters played a substantially central role in their

I wilson and Felen Thomas Follett, Some Modern Novelists: Appreciations and Estimates (1918; rpt. Freeport, New York: Books for Libraries, Ince, 1967), p. 131. 
respective novels, yet were responsible for a great deal of suffering. Is Henchard to be taken as an "ant1-hero?" Add to the list Bathsheba Bverdene, CIym Yeobright, Sue Bridehead, Angel Clare, Fancy Day, Richard Phillotson, and George Melbury, all of whom are Involved in causing some suffering while being essentially non-malevolent, and the complications of choosing villains and heroes and moral guideposts became confusing.

Is a provisional step towards: a better classification of the characters, the characters were divided into four groups in terms of WIII defined as Salf-Control which displays charity to oneself and to others: characters tho possessed a WIII; characters who had a perverted WIII; characters who had no Will, except as they Iived through another's WIII; and Innocent" characters who were searching for a Will while trying to retain their innocence.. Recognizing that many of the "innocents" were tainted, and recognizing that those who had perverted Wills were not alvays selfish and evil, the categories blurred and seemed finally to be Inadequate for interpreting how Hardy's fiction operated. Again, the classiflcation was too easy.

Taking into consideration Hardy's caution not to throw away the whole because the superficies are extravagant, ${ }^{2}$ a question concerning humen will arose; "If Hardy's characters could help themselves to go beyond their suffering, is not the largest stumbling block the Will to make things better?w. The answer was equirocal. Sone characters seemed capable of adjusting and of performing the necessary actions to ward off

2 Thomas Hardy, The Woodlanders, Anniversary ed. (New York: Harper and Brothers Publishers, 1920), p. 1540 
or to overcome disasters; principally, Gabriel Oak and Donold Farfrae. Meanwhile, other characters tried but falled to ward off or avoid disaster, principally Tess Durbeyfleld, George Melbury, Jude Fawley, and. Glym Yeobright. Other characters succeeded partially, as did Diggory Vemn and Grace Melbury. StIll other characters seemed to desire disaster, as with Sergeant Troy, Felice Charmond, Dr. Fitzpiers, and Damon WIIdeve. Michael Henchard and Farmer Boldwood did not want disaster, but found it anywaj.

One point seemed fairly certain. To bleme disaster on a malignant universe," an "Imanent WiII," or "Fate" seemed naive. The sufferings of the characters seemed almost wholly a product of their own or of others: actions, decisions, emotions, strategems, and interests. This observation would seem to support Edward Wagenknecht's statement that human beings were at the center of the universe in Hardy's fiction. 3 So It would also seem to follow that human beings were largely responsible for their Fate, and that their Fate was their character; 4

the gradual closing in of a situation that comes of ordinary himan passions, prejudices, and ambitions, by reason of the characters taking no trouble to ward off the disastrous events produced by the said passions, prejudices, and ambitions.5

3 Edward Wagenknecht, wiPessimism" in Hardy and Conrad," College Inglish, $3(1942), 546-54$

4 Thomas Hardy, The Mayor of Casterbridge, Anniversary ed. (New York: Harper and Brotherg Publishers, 1920), p. 131.

5 Florence Enily Hardy, The Iife of Thomas Hardy 1840-1928 (New Yoxk: St. Martin's Press, 1962), p. 120. Hereafter cited as Iife. See Richard I. Purdy, Thomas Hardy: A Bibliographical Study (New York: Oxford University Press, 1954), p. 273, who ascribes the major portion, except most of the last four chapters, to Thomas Hardy's own construction, making this work largely an autobiography. 
This view of human existence in Hardy's novels is not, however, widely shared by Hardy critics. In his book The Victorian Sage, John Holloway works from the view of Hardy's work which is shared by a number of other critics. Holloway sees determinism in Hardy's works, specifically natural determinism; ${ }_{a}$ system of rigid and undeviating law. 6 Human Iffe and consciousness, Holloway concludes, are "wholly subject to the control of Nature....." Because the whole world and all of life are determined and controlled, Hollowas can see signals of the inevitable in the novels in the forn of "proleptic inages" which "hint at the whole determined sequence of things. $n 8$

Hollowey is not alone in his stand on determinism. Perry Meisel in his study of Hardy's major fiction sees determinism in Hardy's flction as both external and internal. There are forces of nature and the universe which externally frustrate man's aspirations beyond acquiescence. Within a man there are limitations of character and temperament which determine also the outcome of man's attempts to rise above simple ways and aspirations. 9

The views which result from seeing determinism in Hardy's works are that life is basicelly futile; 10 that man's will is almost certain

6 John Holloway, The Victorian Sage: Studies in Argument (1953; rpt. London: Archon Books, 1962), p. 252 .

7 Hollowey, The Victorian Sage, p. 265.

8 Hollowas, The Victorian Sage, p. 270.

9 Perry Meisel, Thomas Hardy: The Return of the Repressed: A Study of the Najor Elction (New Haven: Yale University Press, 1972), p. 6 .

$10 \mathrm{~J}$. Hilils Miller, The Form of Victorian Fiction (Notre Dame: University of Notre Dane Press, 1968), p. 117. 
to be frustrated; ${ }^{11}$ that the tragle flaw in life is the universe which makes men as flies to gods, and life a mockery; ${ }^{12}$ and that man is born to unhappiness, and is helpless and without means of escape. ${ }^{13}$ so human will is alwass contradicted by the powers of the world; man must obey the general will of extstence. 14 The best plan in Hardy's world, as Mbert Pettigrew filiott sees it, is resignation. 15

In addition to these basically philosophical aspects of determinism, there are certain factors in Hardy's novels which seem to have a determining influence on the characters' decisions and actions. Among these determining factors mag be included such aspects as poverty, social class, Time, and Change. Poverty, for example, nay constrain a character to act contrary to his or her feelings, sensibilities, or desires. One instance is Tess Durbeyfield who, seeing herself as guflty for the death of the family's horse through negligence, feels that it is necessary to submit to her mother's plan to go to the D'Urberville estate to try to help her family solve, at least in part, their problems of penury. Later, Tess submits to Alec's advances and becomes his mistress in order to keep her family from starvation and vagrancy.

11 James R. Baker, "Thematic miguity in The Mayor of Casterbridge, ". Twentieth Century Iiterature, 1 (1955), 13-16.

12 Bonemy Dobree, The Lamp and the Lute, and ed. (Londons Prank Cass and Co., 1964), pp. 19, $\frac{\text { 23, }}{340}$

13 Patrick Braybrook, Philosophies in Nodern Plation (1929; rpt. Books for Itbraries, Inc., 1965), p. 39.

14 Lascelles Abercrombie, Thomas Herdy: A Cxitical Study (London: Martin Secker, 1912), pp. 21, 26.

15 Albert Pettigrew Elliott, Fatalism in the Works of Thomas Hardy (1935; rpt. New York: Russell and Russe11, 1966), p. 36 . 
snother example of poverty determining aspects of Iife would be Marty South in The Woodlanders who always had to sacrifice desire to obligation (K, p. 174). Similariy, Jude Fawley was informed that he ought to stay with stone nasonry rather than attempt the university examinations; that is, he ought to stay with his poor social class. wime glides away every day..." (UGT, p. 161). With the gliding awas of Time comes Change which appears in Hardy's novels as inevitable, if even at times very slow and sometimes as too slow as in Jude the Obscure in which Jude and Sue's Modernism": appears to be sacrificed because of their too rapid advances in social behavior. To try to resist change as Michael Henchard seemed to do, as contrasted to Donald Farfrae's embracing of change, is to bring suffering on oneself. At the same time, changes in social structure, for example the change from leaseholds to migrant contracted labor as seen in Tess of the D'Urbervilles, can also bring suffering and inconvenience while failing to solve the problems of poverty and injustice perpetuated by social class structures.

Homan beings and human will have no control, individually, over these determining factors. Quite often it is equarly impossible to control or to influence the effects of these factors. However, Hiliott does not stop at simple resignation. ElIlott suggests that while resIgnation may not bring rellef to man's condition, resignation is Hardy's way for man to live by a higher ethical code than man's maker, whoever or whatever it moy be. ${ }^{16}$ as was seen in the reference to Perry Meisel 
above, there are internal factors in man which help to determine his outcome. This study does not attempt to argue whether or not there are factors in the IIves of the characters which are sometimes beyond the control of the Individual and which may, therefore, be seen as deterministic. The emphasis of this study differs from the critical concentration on Hardy's determinism and determining factors in the novels, which are more pervasive than indicated here, in that this study concentrates primarily on the aspects of existence over which human will may exert some influence or control; on the nature of human relations as they are explored and demonstrated in Hardy's seven major novels; on the causes and the reasons why the men and women are shut out of their beatitude and on the ways in which Hardy indicates that men and women might overcome the conditions which shut them out.

The question of the modern relevance of Hardy's novels has been raised in an article by John Holloway, "Has Hardy Dated?" Holloway claims that Hardy's novels show the reader the Iimitations nature and man's lack of knowledge of nature place on man. In the Twentieth Century, while man has limits to his intelligence and his capabilities to manipulate the elenents of his condition which are seen as only inconveniences, if man overcomes these Iimitations, then Hardy will be dated. 17

Since this study concentrates on human relations rather than on determinism, and since it seems apparent that twentieth-century man has not advanced beyond the problems of suffering in human relations nor has 812.

17 John Holloway, Mis Hardy Dated?" Spectator (Dec. 17, 1965), 
man achleved a recognirabie beatitude, a study of Hardy in human terms epart Irom determinism would seem not to be dated. In the investigation of suffering, human will, evolutionary meliorism, and the possibility of a condition analogous to biblical Grace, the evolution in man of an instinctual will to act through loving-kindness in Hardy's novels, it is hoped that the exploration might prove not only relevant but illuminating in terms of human relations as well as Hardy's art itself. The exploration of suffering, human will, evolutionary meliorism, and Grace will be discussed in separate chapters. Chapter I is devoted to an introduction of the major elements of what is here called Hardy's vision. Relying largely on Florence Emily Hardy's The Life of Thomas Hardir and on references to some of the novels, a compilation of impresslons is arranged into what seems to represent accurateig the basic nature of the world and human relations in Hardy's novels. The emphasis and the thrust of the vision are the ways in wich human doings interrelate.

Chapter II explores suffering largely in terms of its causes. Through descriptions of Individual characters and their relations with other characters, the principal shortcomings of man in his human doings are categorized into two rather basic expressions of human will, selfassertion and self-restraint. It is the extremes of self-assertion, enacted through extreme passions or extreme Intellectuality, and the extremes of self-restraint, expressed through passive acquiescence and social imitation, which are demonstrated as the major causes of suffering in human relations.

The use of suffering for influencing the human will is the thrust 
of Chapter III. After reviewing some critical views of the potential of the human will to affect the human condition in Hardy's novels, examples from the novels of the ways in which suffering influenced decisions and actions are discussed. An awareness of suffering is seen as arousing symathy for the sufferer. The arareness of suffering and the consequent sympathy are evinced as bases for actions and decistons winich work to Iighten some of the suffering or possible suffering of other characters.

Chapter IV concentrates on Hardy's concept of evolutionary meliorism. Using I. H. Huxiey's comments as a background definition of evoIution, It is seen that the ethically better characters tend to survive and to replace characters with non-adaptive, non-athical tendencies. Hardy's novels tend towards evolving an amelloration of man's condition. An investigation of the characters and of the narrative point of view reveals some bases for sadiness and sympathy for all of the characters, making Hardy's viow of evolutionary meliorlsm different from Huxiey's vieu of evolution in human society in that Huxley emphasizes imitation while Hardy seems to enphasize variety as a necessary adjunct to evolutionary meliorism.

A discussion of the OId Testament concept of Grace as analogous to what seems to be Hardy's hope for man is the toplc of Chapter V. Loving-kindness as the motive of human will in aotions and decisions is geen as the result of man evolving a more intense consciousness of the causes of human suffering. As man may evolve an instinctual will to act through Ioving-kindness, so may the Universal Will through its Interralation with man's will, based on connections discussed in 
Chapter I, also develop a consciousness, sympathy, and a new concept of Grace in which a conscious, sympathetic Universal WIII urges, hopefully mercifully, the processes of the universe in place of the biblical concept of God's Grace.

The concluding chapter sumarizes the major emphases of the preceding chapters into a discussion of the moral importance of the use of human will for alleviating as much suffering as possible in human lives and society. The pains and the potentiol of human life which Hardy demonstrates in the novels become the basis for using the worst consequences and possible consequences to motivate mankind to attempt to afford overy man as much relief from suffering as possible.

For the purposes of this study, Hardy's seven major novels are Under the Greenwood Tree (1872), Far from the Madding Crowd (1874), The Returm of the Native (1878), The Mavor of Casterbridge (1886), The Woodlanders (1887), Tess of the DiUrbervilles (1891), and Jude the Obscure (1895). 18 These seven novels are designated as "major" because they are the novels about which the bulk of criticism has been pub11shed. Lascelles Abercrombie clalms that these seven named novels are the novels of Hardy's greatest genius, 19 . In The Victorian Sage, John Holloway indicates that the "NoveIs of Character and Enviroment" espress Hardy's outlook most fully. 20 Holloway names as the best seven

18 The dates are the dates of publication.

19 Abercrombie, pp. $48-49$.

20 Halloway, The Victorian Sage, p. 245. 
novels those novels here indicated as major. 21 Harold Orel, editor of Thomas Hardy's Personal Writings, writes, "for the Wessex Edition, Hardy prepared a classification of his novels, a schema. "Novels of Character and Enviroment were by far the most important category, consisting of nine volumes....."22 Orel includes two volumes of short storfes in the grouping in addition to the seven najor novels.

01 references and quotations from the novels are taken from the Anniversary Edition of the works of Thomas Hardy (New York: Harper and Brothers Publishers, 1920). The Anniversary Edition is an American reprint of the American Autograph Edition, 1915, which was Harper and Brothers' issue of the Wessex Edition in America. According to Richard I. Purdy, Hardy's bibliographer, Mhis edition..was partially printed from the English plates and partialiy reset in merica (in the case of volumes already copyright there)." The English plates are of the Wessex Edition which is in every sense the definitive edition of Hardy's work and the last authority in questions of text. $n 23$

For reasons of convenience and appearance, the quotations and references to the texts of the novels will be given in an interlinear system using the following short title references followed by the page number or, in the case of multiple, contigrous references spread over several pages, by the chapter number:

21 Holloway, The Vtctorian Sage, pp. 288-89.

22 Harold Orel, ed., Thomas Hardy's Personal Writings (Lawrence, Kansas: University of Ransas Press, 1966), p. Xl. Hereafter cited as Orel.

23 Purdy, p. 286. 
WCI - Under the Greenwood Tree

FMC - Far from the Madding Croud

RN - The Return of the Native

MC - The Mayor of Casterbridge

II - The Woodlanders.

Tess - Tess of the DtUrbervilies

Jude - Jude the Obscure

This ahort titile reference systen follows a reference nethod often eaployed in journals and critical studies in the field. 


\section{ACKNOWL EDGESTENTS}

The ideas and the issues wich led to this project were first aroused in my mind during the course of Dr. Sam A. Yorks' class on Thomas Hardy. I would like to take this opportunity to thank Dr. Yorks, my thesis advisor and committee chairman, for his encouragement and his interest wich originally started me and later sustained me in this project. During the course of the research and the writing, his unwavering faith in my capabilities has provided the control without control which helped me through a project undertaken largely independently.

I would also Iike to thank Mr. David A. Holloway and Dr. Ivan Curcin for agreeing to read this thesis and for the hints and the helps which they provided. 
TARLE: OT CONLEIIS

PAGBS

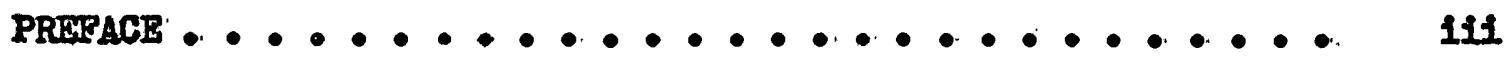

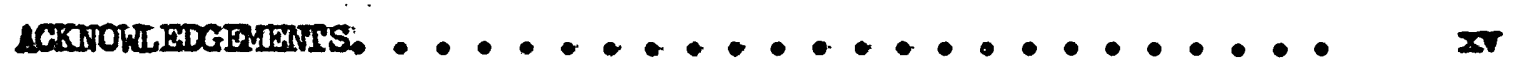

GHAPIFR:

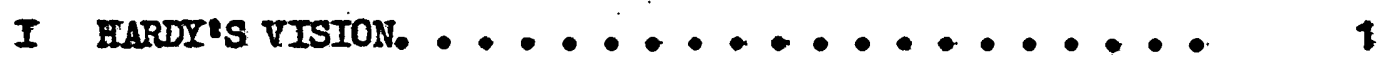

II SUFPERTIG ...................... 18

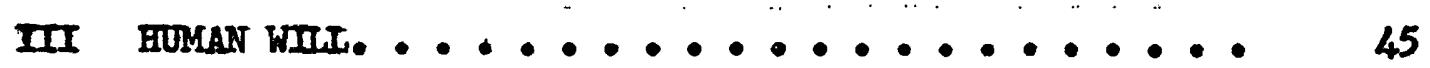

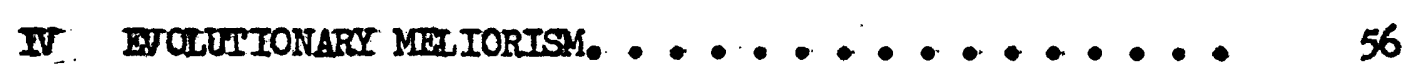

v GRACE ...................... 74

VI CONGUSION. •..................... 82

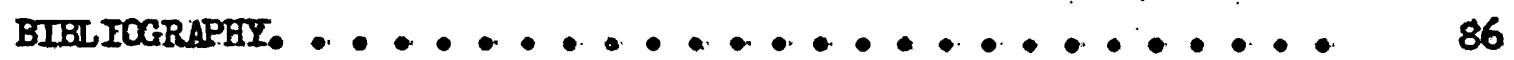




\section{GAPTER I}

\section{HARDI:S VISION}

In the General Preface to the Novels and Poems in the Wessex EdItion, Thomas Hardy denied that his books were designed to show a consistent philosophy; rather, he proported that the books were mere Inpressions of the monent, $n^{2 / 4}$ In the preface to Winter Words, a volume of poetxy published posthumously, Hardy wrote, "no harnonious philosophy is attenuted in these pages-or in any bygone pages of mine, for that inatter. "125 In the sene vein, the preface to Jude the Obscure reports: that this novel is $\mathrm{u}$ an endeavor to give shepe and coherence to a series of seemings; or personal impressions, the question of their consistency or their discordance... being regarded as not of the first noment. ${ }^{26}$

Despite these, and other repeated denials of having described a consistent philosophy, critics have attempted to label Hardy's works as pessimistic, deterministic, and fatalistic. 27 This chapter is not an attempt to categorize Hardy's novels into a specific philosophical system. It is, rather, an attempt to describe the nature of the world, especially the nature of human relations, in the major novels. The description of the vision of a work-its values and attitudes; its ways
24 orel, p. 48.
25 orel, p. 61.
26 orel, pp. 32-33.
27 See preface, pp. v1-ix above. 
of informing the reader's consclousness, expanding, contracting, altering, or reinforcing; its expression of what is knowm, thought, and felt In the experiences which the work describes--is a description of the shaping principle of the wark. This chapter, by using references to the Iffe and the major novels, attempts to describe the basic interrelated nature of the unfierse as Hardy seens to have seen it. This description Is basically philosophical, but it is not necessarily a coherent, consistent system. For the purposes of clarity, the Ideas which Hardy scattered throughout the various writings cited have been brought together to show that Hardy did seen to see that various aspects of existence are, if only imperfectly, related; and that the most inportant aspect of the interrelations in Hardy's novels and for this study is the interrelations among men which take the shape of a "great web of human doings" (W, p. 21).

The nature of the Universe for Thomas Hardy was basically a vast unity animated by the Universal Will. AIthough Handy admitted that mill did not accurately describe the animating force of the universe, he used It in place of words like Power, which implies control; or Impulse, which Implies spasms; neither term was accurate. The Universal Will was seen as "a vague thrusting or urging internal force in no predetermined direction. "n28 The unlimited power of this will was described as being either a blind creative force or as an automatonic force without control.29 Consequentily, the will noves in the direction of the

28 Iife, p. 334. Reliance on the Iife throughout this study is based on its basically autobiographical nature (see note 5 above).

29 Iife, p. 315. 
Ieast resistance. 30

Hardy reflects ideas wich seem to parallel some Victorian scientific thought; such as the creative procedure is a result of expressions of will; 31 all aninals and plants descended from some one prototype; 32 and an, physical, intellectual, moral is as much a part and a product of the cosnic process as the humblest weed. 33 Hardy seems to imply that. man way be equalif. a part of nature as the humblest weed because Bature's creative force is unconcious, blind or uncontrollable, and so neither supports man nor hates man, but neglects him. 34

The umpredictabllity and negligence of nature bring suffering to man, or at least do not prevent man's suffering. There is no Providence In nature which whll extricate men from a mess just because he is himself, whether good or evil. 35. A spot in nature may have beauty, grandeur, salubrity, and convenience, but without menories, it palls into loneliness for man (W, p. 146). It is a part of the vunfurfilled Intention" in nature which seens to promise so much beauty, health, and even,

30 Iife, p. 368.

31 Robert Chambers, Vestiges of the Natural History of Creation, 3rd ed. (Londons John Churchill, 1845), p. 159.

32 Charies Robert Darwin, The Origin of the Species, Author's

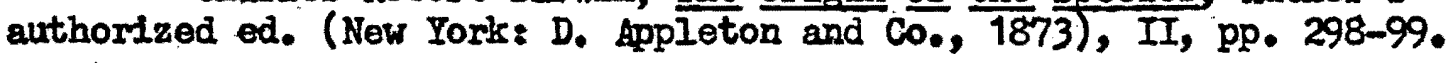

33 Thomas Henry Huxiey, Evolution and Ethics and Other Essays, 1902; rpt. as vol. 9 of Collected Essars (New York: Greenwood Press, Pubrishers, 1968), p. 11 .

34 Iife, p. 48.

35 Roy Morrell, Thomas Hardy: The Will and the Way (Kuala Iumpur: Unfrersity of Malaya Press, 1968), p. 17. 
at tines, happiness. The Unfulfilled Intention seems to be, at times an aparent perversity; when there was a birth in a lonely and inaccessible place, it happened at night (W, p. 136). Most often, nature is simply negligent, unheeding.

In Under the Greenwood Tree, a rainstorm at an inopportune moment brings Fancy Day to the brink of breaking her engagement with Dick Dewy. The storm does sponsor a situation from which feelings arise to produce "ia secret she would never tell"(UGT, p. 21T). In Far from the Madding Crowd, a storm comes and destroys Farmer Boldwood's crop while he is in the throes of depression about Bathsheba Iverdene's marriage to Sergeant Troy. During this same storm, Troy and his workers are celebrating the marriage. Not only weather, but Gabriel Oak's younger sheep-dog manifests blind natural impulse and runs the sheep so thoroughly that ho Orives them into a pit, ruining Gabriel's chances as a sheep-famer.

In The Return of the Native, a hot sun tired Mrs. Yeobright on the day that she went to visit CIym and Eustacia for a reconciliation. During her return hone, she lay down on a furze-faggot, fell asleep, and was bitten fatally by an adder. On the night of Eustacia's attempted flight from the Heath and Clym, the rainy darkness rendered the lendscape unrecognizable, and she fell into a weir. The weather neither helped Bustacia's escape nor prevented Clym's loss of a wife and a mother. In The Mayor of Casterbridge, the rains on a festival das suined Henchard's festivities, but promoted Farfrae's. The harrest weather, first sun, then rain, sealed Henchard's financial ruin, and Farfrae's success.

In The Woodlanders, a stranger coming to Little Hintock at 
sumer's decline would not have known that a woman's fate hung in the balance. Giles Winterborne died from consumption aggravated by sleeping in the rain on the night when his symathy and scrupulosity moved him to give his hut to Grace Melbury. In Tess of the DiUrbervilies, Dame Nature gave Tess an "exceptional physical nature" which incited her being raped, yet was no help in itself against Angel Clare's rejeotion of her. In Jude the Obscure, the rains on the day of his last visit to Sue Bridehoad aggravated Jude's consumption fatally.

1Ithough weather is the most obvious of Nature's oblivious manifestations, as in these above instances, Gabriel's dog, Tess's and Arabella Donn's physical endorments, the movements of the stars (by which Gabriel told time), seasonal changes in plant and animal iffe, and the tides are equally important manffestations of Nature's general negligence of human interests and affairs. The influence which the agents of nature have on the outcome of human doings may really seem often to be malevolent because of the timing of the natural phenomena colncides with the failure or the disaster of a particular character. Yet, as with Donald Farfrae, the events which brought disaster to others worked to help him. More importantly, because Hardy concentrates on the individual's reaction, feelings, and thoughts, when natural elements strike a blow, the tendency of the reader is to see the natural events as the scapegoat for failings. Perhaps more accurately, natural phenomona may be described as contributing to the extrenity of man's sufferIngs in elrcumstances which an additional blow seems unjust and therefore malevolent.

Yet, because Hardy saw the forces of nature as efther blind or 
uncontrollable, that is without effective consciousness of their actions, to ascribe melevolence to coincidence in situations in which the characters obriously take no account of the possibllities and the actualities of natural phenomens is to clrcunstantially ascribe a characterist1c which is not necessarily consistent with the nature of the forces. Fina ily, in most of the cases in which natural impulses, fnclading weather but not man's impulses, contribute to the extremity of the consequences, hwan-caused suffering is already present and sometimes was the agent which drove the character into the circumstances in which weather, for example, could have an affect on the outcome.

Despite Nature's neglect of man which often brings him suffering, Hardy demonstrates the Interrelation and the basic unity between man and Nature in the description of Egdon Heath in The Return of the Native. Egdon Heath is related to Time; it "added half an hour to evening; it could... retard the dawn, sadden noon....," and contribute half of the night's darkness. The Heath anticipates storms and recelves and adds intensity to tempests and mists; "the storm was its lover, and the wind its friend"(RN, Bk, 1, Ch. 1). Human elements are related to the Heath also. A Celtic burial barrow nformed the pole and axis of this heathery world." At the beginning of the novel, a human figure was standing atop the barrow. The human figure completed the symmetry and the unity of the Heath.

Such a perfect, delicate, and necessary finish did the figure give to the dark pile of hills that it seemed to be the only obvious justification of their outline. Without it, there was the dome without the lantern; with it the architectural demands of the mass were satisfled. The scene was strangely homogeneous, in that the vale, the upland, the barrow, and the figure above it amounted only to. unity. (N, pp. 13-14) 
In addition to the interrelation of $\operatorname{man}$, weather, and inanimate nature in an universe unifled throughout, later in The Roturn of the Hative, Clym Yeobright explained another relation between man and nature, admitting that the Heath, to his mind, was most exhilarating, and strengthening, and soothing"(RN, p. 220). In Far from the Madding Crowd and The Woodlanders, the interreletions of nature and man are expressed in other animated relations. In Far from the Madding Crowd, Gabriel Oak told time the sun and the stars. Gabriel forecast the weather from Nature's indications. A heated breeze, bouvant clouds, a lurid metallic-looking moon, and the imminence of thunder warned Oak of a coming storm. Besides these warnings in the sky, Oak observed that the sheep walked head to tail, the rooks behaved confusedly, the horses moved with timidity and caution, a toad sat on a footpath, and a garden slug and some spiders took shelter in his hut. The behavior of the animals "was Nature's second way of hinting to him that he was to propare for foul weather" (WMC, pp. 274-79). In The Woodlanders, Giles Winterborne was described as the "fruit-god" and the wood-god" (W, p. 335). Giles had the touch that brought freshly planted trees to quick root. In turn, the trees seemed to share a sense of life equivalent to humans; "they sigh because they are very sorry to begin iffe in earnest-just as we be " $(\mathrm{W}, \mathrm{pp}, 72-73) .36$ The animating force of man, plants, and animals would seem to be kindred.

Egdon Heath, the animals, the plants, and man are manifestations

36 For a catalogue of Hardy's use of human anatomy in his descriptions of nature, as a further indication of the interrelation of man and nature, see John Holloway's essay on Hardy in The Victorian Sage. 
of Nature's organic and sentient. unity. Whe discovery of the law of evolution....revealed that all organic creatures are of one family...." 137 Since Hardy believed that man's will is a part of the unity of the Universal Will, and since the will of man and some animals is already conscious, Hardy could see the posalbility of a tendency for the whole to develop as these parts have; for the Universel will to become gradually more conscious and, hopefully, sympathetic. 38 Until the Universal Will does evolve into consclousness and symathy, if it ever does before the destruction or the exchaustion of man or the globe, 39 it is important for man to develop his consclousness and his sympathy in an altruism for the whole conscious world collectively in the hope of eventually Informing the Universal will. 40 Since, however, the questions of the existence of God and of the earth's movement through space are too large to be important in human affairs, 41 for Hardy, the most important aspect of Nature's vast organic unity was always man. In showing human iffe against the background of a vast universe, Hardy wanted "to impart to readers the sentiment that of these contrasting magnitudes the small might be the greater to them as men."12 As Edward Wagenknecht points

\section{Life, p. 346. \\ 38 Life, p. 335. \\ 39 Thomas Hardy, "Apology to Late Lrates and Earlier, " Collected} Poems (New York: Mackilian, 1958), p. 527 .

40 Iffe, p. 346.

41 Life, p. 282.

42 orel, p. 16. 
out, In Hardy's novels, the focus of the universe is on man. 43 However, the energy which drives man's passions and intellect can be as negligent of human affairs and interests as the unconcious Universal Will. A measure of the negligence of man's naturel impulses is evident to the degree that a person believes himself right because he is himself, and other people are wrong because they are not he. 44 Man needs to understand his natural relation to his fellows. Therefore, Hardy displays a concentration on man in the novels in various ways.

Just as the universe has an organic unity, the human race is "one great network or tissue." 45 In The Woodlanders, Hardy calls the interrelations of humans a "great web of human doings."

Hardy anything could be more isolated or more self-contained in the lonely hour before day, when grey shades, material and mentel, are so very grey. And yet their lonely courses formed no detached design at all, but were part of the pattern in the great web of human doings then weaving in both hemispheres from the bite Sea to Cape Horn. (W, P. 21)

Hardy recognized the autonomy of individual lives, often lonely and isolated. At the same time, the actions of an autonomous being affect the Iives of other autonomous beings. It is the reciprocal influence among individual lives which forms "the great web of human doings." As one manifestation of the "web of human doings, "Hardy has the major and minor characters meet and remeet in recurring situations and places. In Under the Greenwood Tree, Fancy Day is enmeshed with all of the characters. Her coming to Mellstock parish Involved her with the

$$
\begin{aligned}
& 43 \text { Wagenknecht, p. } 548 . \\
& 44 \text { Life, p. } 165 . \\
& 45 \text { Life, p. } 177 .
\end{aligned}
$$


displacement of the quire. She was the love and, later, the wife of Dick Dewy. She had a brief entanglement with Parson Maybold. She was the object of Farmer Shiner's attention who, as a churchwarden, pressed for Fancy's Instaliment as organist in place of the Quire. Her strategy of starvation, designed to overcome her father's resistance to her desire to marry Dick Dewy, involved, at least financially, a butcher, a baker, and a dairyman. The web of incidents in the novel reflect continually Fancy's presence in the parish. No incident or event transpired which was not in some way related to Fancy.

What is true of Fancy's role in Under the Greenwood Tree is true of the central character in each of the other novels. In Far from the Madding Crowd, the events are related, at least indirectly, to Bathsheba Bverdene; In The Roturn of the Native, to Clym Yeobright; in The Mayor of Casterbridge, to Michael Henchard; in The Woodlanders, to Grace Melbury; in Tess of the D'Urbervilles, to Tess Durbeyfield; in Jude the Obscure, to Jude Fariley. While the relation of events to the central character is not unique to Hardy's fiction, in many wajs it is a very normal and standard procedure, Hardy would see the method as a correlative of human relations outside of fiction, and more as a correlative of the relations among parts of the whole of natural and universal organic unity, especially the "web of human doings." Hardy's novels are $n_{2}$ busy world of events and processes and interrelations. $n 46$ The "wob of human doings" is seen as further reflected in a manmade habitat by John Paterson, Howard O. Brogan, and Bert G. Hornback

46 Hollowgs, The Victorian Sage, p. 254. 
who discuss, in separate articles with separate emphases, a manlfestation in Haris's The Mayor of Casterbridge of the organic wab of the universe. Paterson suggests that Casterbridge stands in a "virtualiy religious interdependence" with man. 47 Brogan explores the physical details of the oity showing the relations among the types of physical features-inns, bridges, houses-and the soctal classes of the inhabitants. Brogan contends further that the city's physical features represent "vistble essences" of "abstract thought, " social and individuar.48 Hormback, working from his consideration of time condensation in Hardy's novels, shows Casterbridge as a place full of the past and its influences. The graves of Roman soldiers, the amphitheater, and the history of human Iife in the oity are seen as Impinging upon the present. 49 These critical views of the novel support the idea that through the interrelations of man, physicel feature, social structure, and history. Casterbridge, as a setting, becomes a form of the world in the novel. Indeed, only two major events occurred outslde the vicinity of Casterbridge; Henchard's sale of his wife, and Henchard's death. In any concept of a moral world as represented by Casterbridge, these erents are outside that world. At the same time, the interdependence of time, place, and man brought even these outside events into the

47 John Paterson, "The Mayor of Casterbridge as Tragedy," Victorian Studies, 3 (1959), 151-72.

48 Howard O. Brogan, "1Visible Essences' in The Mayor of Casterbridge, " 패, 17 (1950), 307-23.

49 Bert G. Hornback, The Motaphor of Chance: Vision and Technique In the Works of Thomas Hardy (Athens, Obio: Ohio University Press, 1971), pp. 83-108. 
center of the Casterbridge world, as further indication of the "wob of human doings."

The web of reality, as these manifestations of the interweaving of human doings which are at the center of the world of the novels might be called, permeates all of the major novels additionally in the forms of coincidents and recurrances. If the world may be seen as wholly Interrelated while being populated by individual, isolated beings, then colncidents become en expression of the connecting points of otherwise independent Ifies and actions. Dick Dew met Parson Maybold, by coincidence, on the road to Casterbridge in Under the Greenwood Tree. This chance meeting was partially responsible for saving Dick's courtship, marriage, and apparent happiness. Parson Maybold had started on his walk to Casterbridge to post a letter prompted by Faney Day's Inordinate acceptance of his mamiage proposal. Maybold had not knowm of Fancy and Dick's unannounced engagement. Diak knew nothing of Marbold's proposel and Fancy's acceptance. Dick was going to Casterbridge on hawling business. The chance meeting brought together, coincidently, the independent, yet related interests of the two men, connected one step back through Fancy, thus weaving their Ifves into the whole wob of the novel's human doings more furly.

Gabriel Oak reappeared in Bathsheba Everdene'g life in Far from the Madding Growd through the coincldence of a rick fire. Thomasin Yeobright's marriage in The Return of the Native was finalized through the contingencies of the coincidence of her cousin Clym's return to the Heath from Paris. Dr. Fitzpiers' infidelty to Grace Melbury in The Woodlanders received added impetus from the coincidence of his childhood 
encounter with Felice Charmond. Jude's early and later related troubles began with his coincident encounter with Arabella Donn. In the bringing together of lives and actions which are otherwise seemingly independent, the connection of human doings is intensifled into a representation of the effects and the influences which one person or one portion of the family of organic Iife can have upon the whole of the family.

On the whole, the coincidents which arise from the webbing of lives are basically neutral in character. The coincident events which reveal the webing give only opportumities for effects, either positive or negative. Yet, in a world in wich a shock in one quarter reverberates throughout the whole organism, 50 it becomes rery difficult to avold ang negative effects of the organic unity of the world. In addition, the negative effects of any one action can recur. Henchard's sale of his wife became associated with his decline in Casterbridge through the reappearance of the furmity woman in his life. The horrors of Tess's rape and illegitimate child recurred in Angel Clare's rejection of her, a psychological rape, on their wedaing night. Arabella Donn returned to Jude Fawley's Iife continually, especially through their chilld. Fanny Robin's seduction returned to haunt Sergeant Troy. The desire for material advancement sponsored by her father, returned to Fancy Day in Parson Maybold's proposal. Thus, the coincident events which reveal the "wob of human doings" appears to be inescapable. The patterns of recurrance become a form of entrapment. Jude Fauley was never able to escape Arabella, stone masonry, or his dream 50 Life, p. 177. 
of Christminster and the university. Tess became a caged animar, as Indicated, for example, in her learning to whistle from Alec Dיrbervilise who stood outside the hen coop with Tess sitting inside, thus paralleling Tess's duty to teach caged bullfinches to whistle airs (Tess; Ch. 9). Philip Griffith indicates that the trapped-animal image is reinforced throughout the book through coincident, parallel experiences with animals. 51 No character was able to escape effectively from Egdon Heath in The Return of the Native. The characters were unable to escape the influence of their human and natural environment. Likewise, a character cannot avoid Influencing the lives of others. Tess's past sent Angel to Brazil. Marty South's decision to sell her hair in The Woodlanders, the result of George Melbury's plans to marry his daughter with Marty's hoped-for lover, Giles Winterborne, influenced in part Dr. Fitzplers' complioity with Felice Charmond, and wholly, their final separation. Smell and large actions influence others similarly, Hardy seems to indicate.

If individual lives and actions occur in a context of a "great web of human doings," giving and receiving influences to and from each athers' Iives and actions, then the Ilves and actions become less free. As the shocks and pains which one member introduces into the organism circulate and return to the giver, the precautions against initiating shocks become more sensitively established. The moral sensitivity of the Individual grows as man sees the pain "in others' reactions on

51 Philip Malone Griffith, "The Image of the Trapped Animal in Hardy's Tess of the DiUrbervilles, "Tulane Studies in English, 13 (1963), 85-94- 
ourselves, as part of one body." 52 . As moral sensitivity grows and the influence of individual actions on others becomes more a part of the Individual consciousness, decisions and actions become more limited in their scope and use. At the same time; the decisions which remain become more important because they affect more lives. If there may be any wholly or largely free decisions in a world of organic unity, decisions which do not reciprocate influences in individual lives and decisions, then they must be made in isolation.

There are occasions on which an individual may decide. Hardy believed that when the forces which permeate the world, which includes man, are in equilibmitu, free will was at its zenith. This may or may not be often. 53 Hardy was interested in showing that "the intense interests, passions, and strategy that throb through the commonest lives, "54 give individuals a disequilibrium which sponsors the "gradual closing in of a situation that comes of ordinary human passions, prejudices, and ambitions.....55 It seemed to Hardy that, because of these human passions, prejudices, interests, ambitions, and strategies, there was an "inevitableness of character and environment in woriking out desting...." 56 given a definite character in a given situation, a certain result is nearly inevitable. Since the forces which permeate the world

$$
\begin{aligned}
& 52 \text { Life, p. } 224 . \\
& 53 \text { Hardy, Collected Poems, p. } 527 . \\
& 54 \text { Life, p. } 153 . \\
& 55 \text { Life, p. } 120 . \\
& 56 \text { Orel, p. } 118 .
\end{aligned}
$$


include the passions, the intellect, and the will of man, when a time of possible decision arises, If the individual is under the influence of excessive passions or excessive intellect, that is, not in equilibrium, the human will loses much of its ability to choose effectively. Michael Henchard decided to drink rum in the furmity tent, decided to try to sell his wife, and, after several chances to resoind his decision to sell, decided to let the sale stand. The first decision was the only one made while not under the influence of the alcohol which had heightened his normally impassioned character. Similarly, later in the novel, when Henchard decided to fire Donald Farfrae, his accountant and foreman, this deciston was made in a passion of indignation. The freedom of Henchard's decisions was Iimited by his character.

Tess Durbeyfield vacillated between encouraging and discouraging, accepting and rejecting Angel Clare's love suit. She wanted to marry Angel for the acceptance and love she believed marriage would offer in contrast to her experience with Alec DiUrberville. She wanted not to marry Angel because she felt guilty and tainted because of her past. In either case, her decistion had to come under the influence of the past.

It seems appropriate to conclude that if, as with Tess and Henchard and many of the other characters, the contingencies of character, the past, and the Iives, actions, and decisions of others influence each now situation, the times are therefore seemingly fow when the forces which permeate the world and affect human lives are in equilib rium; allowing uninfluenced decisions or actions. For, in an universe which is characterized by an organic and sentlent unity, in which Time, 
place, weather, man, animals, plants, and inanimate nature are interrelated, the "web of human doings" brings individual, autonomous, and apparentIy isolated Iives into constant juxtaposition, thus making the individual Iife and the human w1I subject to a multitude of influences, past and present, in every situation. The suffering which may arise and be transmitted in the "web of human doings" to affect human life and will is anelyzed at its sources in the next chapter. 


\section{GHAPIER II}

\section{SUFFERTIK}

For Hardy, "pain has been, and pain is.... 457 Suffering is a fact of human existence. Just how much suffering may be attributed to the nature of the world and how much to purely human causes seems to be beyond calculation. Yot if it is considered that human beings form the focus of the novels, then it may be also considered that the sufferings of humans and the human causes of suffering form an important central aspect of Hardy's novels. Since Fardy seems to regard pain as an established fact of human existence, as Indicated above, knowing the causes of pain and suffering, particularly the human causes, becomes central to any desire ar atterupt to alleviate suffering. In Hardy's novels, the human causes of suffering mas be divided into extreme selfassertion, either through extreme passions or extreme intellectuality, and extreme self-restraint which leads to passivity and acquiescence both to the natural order and to the man-made order of society.

Hardy was concerned with Whow to afford the greatest happiness to the units of human society during their brief transit through this sorry world.... 58 He proposed that mankind should magnify good works, and develop all means of easing mortals" progress through a world not worthy

\footnotetext{
57 Iffe, p. 315.

58 0xel, p. 20.
} 
of them, $" 159$ Pain "ghall be kept down to a minimum by loving-kindness, operating through scientiflo knowledge, and actuated by the modicum of free will conjecturally possessed by organtc life...." To acquire scientific knowledge for man's betterment, man is required to take "a furl Iook at the Worst" which entails an "exploration of reality, and its frank recognition stage by stage along the survey...," including answoring such "obstinate questionings" and "blank misgivings" which arise. The ploration is the first step towards the betterment of soul and body if man keeps an eye on "the best consumation possible: briefly, evolutionary meliorism. "60 To the extent that Hardy's works take man "forwards, even if not far, rather then backward" ${ }^{61}$ as $\mathrm{na}_{\mathrm{a}}$ lesson in Iife" and "mental onlargement, "62 the works mas be seen as a part of a survey of the sources of suffering and an exhibition of the means, and the possible results, of keoping pain to a minimum and affording "the greatest happiness to the units of human soclety...."

Pertiaps the worst aspect of human life, for Hardy, is suffering. Within the vast context of interrelations in which mankind Iives, the sources of suffering can be as extensive as the number of individuals. In the major novels, the sources of suffering may be seen as the outgrowths of excessive self-essertion and of excessive self-restraint. One of the forms of excessive self-essertion appears in behavior guided

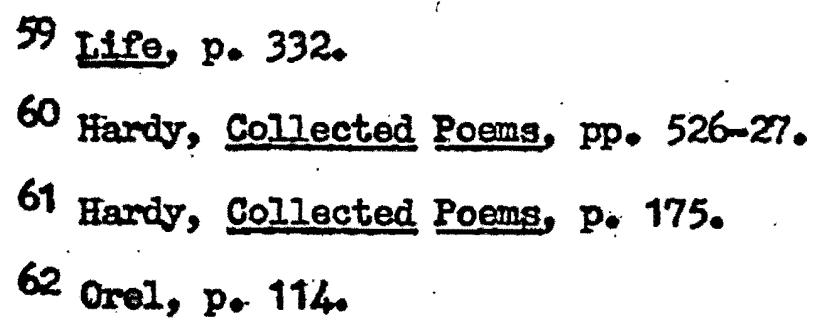


bo the emotional excesses of jealousy, selfishness, pride, possessiveness, desire, or impatience. Another form of excessive self-assertion appears in behavior guided by intellectual principles which do not temper general principles with specifle instances, Judge deeds by the will, or combine reason with emotion and action. Excessive self-restraint eppears in the form of negligent passivity, either in the present. or to the past, and engenders initation of unjust, insensitive, and unvirtuous social conventions.

The extremes of self-essertion, most evident in decisions and actions based on etional motives, are the most noticeabIe causes of suffering. Jealousy, selfishness, pride, possessiveness, desire, and Impatience are the forms of negative passion: which most often lead or contribute to suffering. There is hardly a major character in the seren major novels who is not at some time raled by some extreme of passion. To show the several ways in which the extremes of passion operate in the novels, it is necessary to revien some of the characters who are most swayed by passionate extremes.

Sergeant Troy, for example, appears in Far from the Madding Crowd as a product of rootless, military, and industrial acquisitiveness. Troy is a character who flaunts social restraints. The instinct of unlimited self-assertion whioh he brought into the world as each newborn child does, 63 has never learned the necessary self-restraint and renunolation. Troy is all burning desire; his emotions work like Iightning (WMC, p. 201); he enjoys the pleasure of letting his feelings out "on 63 Huxley, p. 440 
the spur of the moment"(FMC, p. 196). He wanted to have, to hold, and to conquer; but he was inconsiderate and non-reciprocating. He is a character of imresponsible freedom; an "erratic child of impulse" (BMC, P. 202).

The first encounter with Troy in the novel is his relation with:

I Fanny Robin. He captured her heart and her body, but he was unconcerned about lending support to Fanny's needs. He delayed maryying Fanny. When Troy did finally offer to marry her, but she went to the wrong church, the minimal self-restraint which lod him to offer to marry subsided in a passion of embarrassment and pride. After having waited alone before the church alter under the inquisitive gase of the parishIoners, Troy told Fann,, "I don't go through that experience again for some time, I warrant youl" (FMC, p. 131).

After his experience with Fanny, Troy fell on Bathsheba Frerdene. Trof's passionate nature: gave his personality a flashy attraction which dren Bathsheba to him. The strord exercise scene in Chapter 28 in which Troy dezzled Bathsheba with the "circling gleams, "the "keen rush," and a "scarlet haze" of his "gurora militaris, displays Troy's attractiveness to Bathsheba. While Mroy's reflecting blade...seemed everywhere at once, and jot nowhere spectally" (YMC, p. 211), Bathshebe "relt power 1eas to withstand or deng him"(FMC, p. 213). Troy Ieft the Army, which he hed foinod orjginaliy to escape the constraints of his background, to marny Bathsheba as another escape from restraints. At the estate ho did not need to work, nor did he worry about estate business. He could Iet the grain rot in the ricks while satiating himself with alcohol. Having conquered Bathsheba, represented by their marriage, Tros 
reciprocated no emotional support to Bathsheba. As Fanny Robin before her suffered and eventually died in the unionhouse, Bathshebs suffered from the caprices and self-indulgence of her nominal husband. Troy's Iife was a life of aimless, passionate freedom which had no control, sustaining power, or oharity. Troy's extreme self-assertive passions were responstble for much of the suffering in Far from the Madding Groud.

Similar to Troy is Bustacia Vye in The Return of the Native who has the dark eyes of passion.

Sho had pagan oyes, full of nocturnal mysteries and their light.... issuming that the souls of men and women are visible essences, you could fancy the colour of Eustacia's soul to be flamelike. The sparks from it that rose into her pupils gave the same impression. (RN, P. 76)

Onif occasionaliy was hor passion cooled, and then only for a moment when the object of her passion appeared defective.

thenever a flash of reason darted like an electric light upon her lover-as it sometimes: would-and showed his imperfections, she shivered.... But it was over in a second, and she loved on. (RN, pp. 73-74)

Thus, when Clym Yeobright returned to Egdon Heath, Bustacia saw Paris arise on her horizon. Eustacia's sphere of passion expanded into a dream vision of higher passion through Society (RN, p. 79). Paris was her Mecca. where she longed to feast on the grandeur of flashy, showy oircles of people who could, she believed, excite her passions eternal1y. To this end, she set out, quite appropriately as a heathen knight, to conquer Clym whom she believed to be her passport to the passions of Paris. She had no real, lasting desire for Clym. She wanted Paris and was willing to sacriflce him for her self-gratification. When Clym did 
not fulfizl her passion for Raris, Eustacia made her own plans and attempted to run away with a former lover. Eustacia was driven variously by her pride (in her disdain for Clym's furze-cutting), her jealousy (In her fear that Clym would marry Thamasin), and her great desire "to be Ioved to madness." The result of Eustacia's wild passions was the deaths of herself and two others, and the near-death of another who spent the remainder of his life in lonely, self-recriminating isolation. Bustacia's wild, passionate longings, fealousies, and pride involved her at the center of the causes of suffering in the novel.

Michael Henchard's passions take a different form in The Mavor of Casterbridge; possessiveness. He desired to have a firm, controlling grasp on the situation and on the people around him. One of many aigns of Michael's possessiveness is the selling of his wife which was the act of a merchandiser selling his wares. Michael's desire to have Hizabeth-Jane take the name of Henchard is just one indication of his attempts to possess people. For with his name attached to her, she would be more readily recognizable as his appurtenance. Michael's possession of Casterbridge is in part indicated by the sign boards throughout the city with his name on them. The majorality is not only the culmination of his climb from the time when he possessed nothing, but is necessary to aignify his possession of Casterbridge. As a resurt of his possession and his desire to possess, Henchard hired Donald Farfrae to maintain and to increase his possession of the area's business.

Ironically, Henchard never possessed himself. The self-assertion which drove his desire to possess made it impossible for him to control his self-assertive passlons. The oath he swore, not to drink for twenty 
gears, derived its power from the same fund of self-assertion as his desire to possess. H1s ready relinquishment of the restraint at twentyyearst and is a sign of his never having achieved self-possession. The pessionate alterations of Henchard's nature which made him, for example, warm and friendly to Farfrae at first then hostile and disdaining, rendered Henchard unable to face adverse circumstances.

As a result of his possessiveness, Henchard was fealous when customers preferred Farfrae's crop valuations, when the Royal Personage visited Casterbridge, and when Farfrae courted Elizabeth-Jane and Lucetta, Henchard's former mistress. So that he would not lose Hilzabeth-Jane, Henchard lied to Newson, her real father, when he came to Casterbridge to find her. The effect of his possessiveness was Henchard's allenation from overyone and everything. Indirectly, his. desire to possess Ied to the deaths of Susan, his wife; Iucetta, his mistress; and himself. Almost all of the forces of evil in the novel are either Henchard's or are a result of Henchard's doings; his possessive instincts are the cause, directly and indirectly, of most of the suffering.

Felice Chamond, in The Woodlanders, is an example of how extreme passions can affect the mind and the behavior of a character. She is a wowan with

passions of no mean strength--strange, smouldering, erratic passions, kept dow like a stifled conflagration, but bursting out now here, now there-the only certain element in their direction being its unexpectedness. (W p. 233)

She complained, "0l why were we given hungry hearts and willd desires if we have to Iive in a world I1ke thisl"(W p. 237). Felice is a woman 
of perversities who Ilkes "mystery in her 1ife, in her 10ve, in her history"(W, p. 234). Hex soul was "slowly Invaded by a delirium.... losing judgment and dignity under it, beconing an animated impulse onfy, a passion incarnate" (W, p. 281). Because of her delirium of passion, Felice could not keep faith with Grace Melbury and so finally eloped with Grace's husband, Fitzpiers, causing misery for Grace and her father. Felice was killed by a former victim of her passionate caprices, thus displaying how the suffering caused by extremely passionate behavior and introduced into the "web of human doings" can recur in human Iife.

Similarly, Alec DiUrbervilie, in Tess of the DiUrbervilies, displajed a continual passionate desire, most often centered on Tess. Alec's passion involved him in affairs with his farm maids, and led him to rape Tess. He was too proud and too self-assertive to help or to support Tess except as her support might further his possession of her. After Tess went to Talbothays, eventually to mary Angel Clare, Alec turned to extreme evangelism. The same self-assertion which fed Alec's desire for Tess drove his evangelism. His assertiveness was merely Iaunched towards new objects, temporarily. When he met Tess again, he reverted easily to chasing her. Now he was also jealous of Angel Clare because Angel had Tess's heart. Because Alec was Impatient to have Tess, he pushed against her continually to sever her bond with Angel, trying to destroy Angel in Tess's heart; an attempted emotional rape similar to the earlier physical rape. Aleo offered to house Tess's mother and siblings to gain possessive, physical control over Tess. FInaliy, the workings of Alec's self-assertion brought him violent death 
and led to Tess's death. Alec's pession Iay behind much of Tess's, and subsequently Angel's misery and suffering, putting Alec's passionate assertions among the central causes of suffering in the novel.

Arabella Donn, in Jude the Obscure, displajed her passionate extremes in the manner of an earthy creature. Her passionate nature is perhaps nowhere better illustrated than in her throwing the pig's pizzle at Jude; "the characteristic part of a barrow-pig, which countrymen used for greasing their boots..." (Jude, p. 41). The "characteristic part" being of "a soft, cold substance, " it is characteristic of Arabella's passion. Her desire for Jude had a sensual aspect which was cold in its lack of reciprocity; she had a selfish instinct for love. As D. H. Lawrence indicates, because of her selfish passions, Arabella refused Jude's purpose. Arabella did not want Jude, she only wanted the sensation of herself in contact with him. 64 When Jude seemed unable or unwlling to satisfy her desires, Arabella embarked for Australia and took on a new lover there. When she returned, she pushed her son by Jude onto Jude and married a second husband. When the second husband died, Arabella directed her passions, like Alec DiUrberville, into ferrent religion. Seeing Jude again, she cast off religious passion for seacual passion and retrapped Jade into a second marriage. When Jude was too siak to satisfy Arabella, she left him on his deathbed to join the sensuous festivities of the boat races where she consorted with a quack doctor who sold love philtres. Arabolla's passionate

64 D. H. Lawrence, "Study of Thomes Hardy, "Phoenix: The Posthumous Papers of $\mathrm{D}$. $\mathrm{H}$. Lahrence, ed. Edward D. McDonald (New York: The Viking Press, 1936), pp. 493, 495. 
comings and goings In Jude's IIfe are a part of "the contrast between the ideal Iffe a man whed to lead, and the squalid real life he was fated to lead." 65 Arabella, in her passionate comings and goings, was one of the major causes of the squalid misery of the novel.

While these characters of extreme self-assertive passions brought about their own demise through forces they unleashed, their avoidance of death and the deadiy situation was strong. Their self-assertion seems to have driven the characters to seek pleasure and to avoid suffering for thomselves without regard for the suffering which they might cause others; to have given them a selfish passion for life. Sergeant Troy struggled heartily to survive being consuned in the sea. Eustacia Vye struggled to survive Egdon Heath by trying to escape it. Henchard's oath against alcohol was part of his attempt to survive. He needed to avold drink if he was to have any chance to survive the erratic nature of his passions. Henchard struggled also against suicide when he saw his ow dead figure in the weir. Felice Charmond tried to escape a disappointed lover and the disapprobation of Hintock in Burope. Alec Drurberville tried to hide away from the contingencies of the possible return of Angel Clare at the seashore. Arabella Donn was the only character of extreme passions who successfully maintained the survival-orientation which the other characters displayed but could not maintain. Despite the selfish passion for life which extreme self-assertive passions gave them, these characters suffered from their own passions just as other characters dic.

\section{5 iffe, p. 272.}


Solf-essertion appears in other characters in both conventionel and contorted forms. Coorge Melbury in The Woodlanders had the conventional desire to assert himself through his daughter, Grace, and so to raise her Into Society. He sent her to training sahool and then married her to a doctor of an 01d, but fallen family. The "intense consoiousness" which Grace received from the schooling and the capriclous nature of her husband brought her suffering. In The Mavor of Casterbridge, on the other hand, Iucetta Le Sueur displayed a contorted self-assertion which appeared as a desire to bo possessed, and to be the primary possession. She plotted her affatrs so that she married the rising Farfrae rather than the declining Henchard, her former lover. Her plottings brought sadness and chagrin on herself, on Elizabeth-Jane, and on Henchard. Boldwood's attempt at self-assertion in Far from the Madding Crowd ran to insanity. Having been inflamed by a Valentine, Boldwood neglected his business affairs in longing and remorse for Bathsheba. He became totaily unbalanced, buying great stores of clothing and trinkets for the woman whom he could not be sure he might marry. When Bathsheba's husband returned from a mysterious absence during which he was assumed to be dead, Boldwood shot-the husband and surrendered himself at the county jail. Whatever form the self-assertIve passions took, and the forms were numerous in Hardy's novels, when those passions were allowed to operate without consideration of the consequences or without regard for others, the result was invaribly suffering for the others and the impassioned one, and included death.

In contrast to the characters who seem ruled by extreme passions, 
there are several characters who are basically very intellectual, who seem to lead their lives as rationalists. The rational characters found little comfort in Christianity because of the errors in 1ts logic and Its premises. In many wass, the apparently rational characters display negative attitudes towards society and people as well as religion. These negative attitudes tend to promise improvement for man and for society. A rational approach to situations and problems seems to avoid the excesses of passion which are selfish, possessive, or jealous. Additionally, a rational approach has, for Hardy, an "accessibility to new ideas" as well as, with its tendency to find errors in traditional thought which give rise to negative attitudes towards such errors, a corresponding "emancipation from those [Ideas] which reveaI themselves to be effete." 66 At the same time, Hardy shows the reader that the excesses of intellect may be similar to the extremes of passion and so may cause suffering as much as excesses of passion.

The intellectually oriented Angel Clare in Tess of the DiUrbervilies is the youngest son of a parson. While his two older brothers studied at Cambridge for positions in the church, Angel decided that he could not honestly be ordained a minister as long as the church refused "to 11 berate her mind from an untenable redemptive theolatry" (Tess, p. 149). Angel wanted to use his intellect and his education for "reconstruction;" for "the honour and glory of man..." (Tess, p. 150). His studies Ied him "to evince considerable indifference to social forms and observances"(Tess, p. 150). Family name and history and 66 Iife, p. 318. 
material distinctions were considered worthless without "good new resolutions." Angel valued intellectual liberty most (Tess, p. 151).

Intellectual liberty is subject to the same problems as the freedom of the human will discussed above. If an intellectual life is to have and beneficial importance, it must consider the context of the nvob of human doings." A man's mind may be capable of rational, intellectual liberty, bounded only by its capacity. However, actions based on intellectual liberty to be beneficially important must be considerate of others. This consideration places a limit on the actions which may be derived from rationality. Therefore, full intellectual liberty without painfur consequences appears to be possible only in the isolation of the individual mind in the world of Hardy's novels.

Within the remote depths of [Angel's] constitution, so gentle and affectionate as he was in generel, there lay hidden a hard, logical deposit, like a vein of metal in a soft loam, which turned the edge of everything that attempted to traverse it. It had blocked his acceptance of the Church; it blocked his acceptance of Tess. Moreover, his affection itself was less fire than radiance,... when he ceased to believe he ceased to follow-contrasting in this with many impressionable natures, who remain sensously infatuated with what they intelloctualiy despise. (Tess, p. 308)

With this Mlogical deposit," Angel faced Tess's revelation of her past not as "a question of respectability, but one of principlel "Tess, p. 308). As Tess recognized, Angel's consistency was too cruel (Tess, p. 309). When Angel decided that they must separate and awake the following morning with the intention intact, he regarded it as standing "on a basis approximating to one of pure reason..." (Tess, p. 320). Angel's consistent intellectual liberty, carried into action, became cruel infustice. Excesses of intellect untempered with loving-kindness, the result of applying general principles without regard to specific 
cases, resulted in suffering.

Sue Bridehead in Jude the Obscure displesed a combination of spiritual and intellectual qualities. Sue's intellectual qualities parallel Angel Clare's to a certain extent. Her intellect sparkles Iike diamonds..." (Jude, p. 276). She is described as a "Voltairean" (Jude, p. 182) who reads Gibbon, J. S. Mill, Shelley, Himboldt, and Swinburne. Sue rearranged her New Testament chronologically to make it "more interesting and more understandable"(Jude, p. 152). Her respect for Christminster was for its intellectual side only.

This "nature not so passionate" which was the "spirit of Sue," a mind incarnate, is "all nervous motion." She had a nervous quiver, a nerrous lightness, and a nervous quickness. When her face was set, it was nervously set. She stood like a vision but was as anxious as a dream. Sue's combination of spiritual and intellectual qualities, rather than being pure rationalism, are closer to what Hardy called, In The Woodlanders, "modern nerves."

Sue's intellect is housed in an almost amorphous body. She is described throughout the novel in terms like "light and slight, " "lightfooted," "quick, light voice," "slight figure," "soft glance," "thin Iips," "silm and fragile being." Sue is an "aerial being." As such, Jude described her as a spirit, a disembodied creature, a tantalizing phantom, hardly flesh at all: when I put my arms around you I almost expect them to pass through you as through airl" when sue described herself from Shelley's "Eipsychidion"-

There was a Being whom my spirit oft Met on its visioned wanderings far aloft. 
A. Seraph of Heaven, too gentle to be human, Velling beneath that radiant form of woman...

-Jude replied, "It is you, dear; exactly like youl"(Jude, p. 294). Sue's intellectual and spiritual nature, marked by intense nerves, is "the ethereal, fine-nerved, sensitive girl, quite unfitted by temperament and instinct to fulfill the conditions of the matrimonial relation with...possibly scarcely any man..." (Jude, p. 263).

The ethereality of Sue's nature lent her a prudery. She had a physical objection to her husband, and, apparently, to all men. She had Iived with a man in London for fifteen months without sexual relations. Jude and Sue lived together a year before their first consummation. Public conjecture in the novel described her as cold-hearted and sexless. She hated herself when she felt a "meanly sexual emotion," and immediately afterwards assumed a frigid pride. It was Sue's lack of touch with physical reality which rendered her ostensibly frigid on the one hand and unable to have the courage of her convictions on the other. "Sue's logic was extraordinarily compounded,....things . which were right in theory were wrong in practice." The nature of Sue's compound logic is one that lives in the mind but not in the world (Jude, pp. 262-63).

Because of her disembodiment and lack of courage to practice her theories in physical reality, Sue brought suffering into the lives of Jude, Richard Phillotson, and the former student with whom she had lived in London for fifteen months. The fomer student died of what appears to have been melancholy, derived from a prolonged and sexless proximity with Sue, coupled with consumption (Jude, pp. 177-78). Phillotson lost 
his position as a teacher and was blackballed from teaching when, largely because of Sue's physical revulsion and intellectual arguments, he freed her. Jude was left to the Ionely aimlessness of his crushed dreams after the deaths of the children when Sue returned to Phillotson because the ugliness of physical reality was unbearable for her, and so she sought succor in severe, almost monastic spiritualism. Even Sue could not escape the sufferings caused by her temperament. Sue's spiritual, nervous intellectuality ended in physical scourgings for herself. The extreme intellectuality displajed in Sue's disembodied spirit and intellect is, then, a dissociation from reality which because the dissociation precludes effective consideration of the physical circumstances of existence, causes suffering.

Sue's nature, which was "so vibrant that everything she did seemed to have its source in feeling"(Jude, p. 120), reveals another aspect of extreme intellectuality represented by Dr. Fitzpiers in The Woodlanders. Dr. Fitzpiers had a mkeenly appreciative, modern, umpractical mind" which directed its attention to objects of the inner eye. Fitzpiers' appearance mbespoke the philosopher" who, as a modern man of science, had a social and intellectual interest. During the course of a year, his mind travelled through "the zodiac of the intellectual heaven," studying altemately alchemy, poesy, astrology, astronomy, German literature and metaphysics, anatomy, and abstract philosophy. His constant meditation on the Muses or the philosophers seemed to err in the possession of too many ideas. While Fitzpiers was to a "distinct degree sclentific," he was primarily an idealist who felt that behind the imperfect, the perfect lay ( $\underline{W}, C h .17)$. Not being a practical man, 
Pltuplers preferred the discovery of prinoiples to their application (W, p. 119).

The result of Fitzpiers intellectual pursuits is to make him, in his own words, Inhuman and supercillous. Wiet me tell you that Brerything is Nothing. There's only Me and Not Me in the whole world." With this attitude, Fitzpiers belleved that "no man's hands could help what they did, any more than the hands of a clock...." (W, p. 55). He belleved that men are only "miserable creatures of circumstance"(Wh, p. 138), and that the human will is powerless against predestination (U, p. 227). Fitzpiers referred to himself as doomed and to events as part of desting and docm. Having embroiled himself in these determinIstic ideas, Fitzpiers" aspect seemed to say that he had "suffered a certain wrong in being born"( $W$, p. 296).

In a deterministic world, "the secret of happiness lay in Iiniting the aspiration..." (W, p. 160). Accordingly, Fitzpiers, following his study of Spinoza, belleved human love to be subjective; a certain joy combined with an idea projected on some object within view. He could be in love only with something in his head not with a thing-in-itself outside (W, p. 138). Simflarly, he felt that sadness and sickness at heart was the end of Iove according to Nature's law (W, p. 232). So marriage ought to be made into as short and simple a civil contract as buying a house or making a will (W, p. 198). Later, during his marriage to Grace, his manner took on the "gcrupulous civility of mere acquaintance" (W, p. 241). Fltzplers' intellectual attitudes rendered him apparently incapable of concern about the human causes of suffering. Hence, he would be unaware of his own forolvement as a source of 
suffering and unaware of the dangerous consequences of not uniting theory and practice which he displayed.

Just as Fltzplers was highly intellectual and educated, he was also capable of being led by passion. His affair with Felice Charmond, sponsored in part by her social position and in part by their idyllic, dreary chilldhood encounter, was based in no way on intellectual pursuits or reasoning. It was the result of bIind passion. The practical shallormess of Fitzpiers' intellectual nature, made the more shellow through his Idealism and determinism, brought suffering into Grace's and her father's Ilves. Hardy seems to be indicating through Fitzpiers and Sue Bridehead that highly intellectual pursults, whether theoretical philosophy or intense, modern, ethereal nervousness, can bring not only suffering, but that the energy of self-assertion behind the intellect Is similar to, if not the very same as, the energy bohind the grosser passions. Sue's modern nerves made her capable of passionate reactions, spectfically her jealousy of Arabella. Fitzpierst intellectual Idealism turned into extreme, adulterous passion with Felice. Whether intellect and passion are ilivminated with the same energy or with different energies, the results of self-assertion in either intellect or passion are clearly, in Hardy's novels, suffering.

Anthough the characters who display the extremes of passion or Intellect would seem to be all "bugtling movement and struggle," Hardy recognized that $\mathrm{k}_{\mathrm{a}}$ more imposing feature of a human mass is its 
passivity; ${ }^{\text {67 }}$ a tendeney to take "no trouble to ward off the disastrous events produced by [ordinary human] passions, prejudices, and ambitions.... " 68 Just as Jude observed that feelings rule human thoughts and actions, feelings are often allowed to rule human will. Not only does the human will fall to ward off disastrous results caused by human passions, prejudices, and ambitions, the witl is allowed to acquiesce to the original impulse which sponsors the passions, prejudices, and ambitions. In so far as the characters who disploy extremes of passion or intellect fall to attenuate their extremes, they may be seen as passive.

There are other characters for whom passivity represents the most noticeable aspect of their personalitios. At times they are capable of strong feelings. They are often, at least nominally, educated. Despite education and strong feelings, these characters have a passivity wich is the result of either severe self-restraint or temperamentally instinctual restraint. The same self-restraint which hinders a character from working actively in a particular situation, lends itself quite readily to social subordination, especially in the form of imitation of social conventions, inciuding those wich have no inherent value. Extreme self-restraint will allow a character to suffer soctal and personal infustices and to acquiesce totally to the processes of nature and "fate."

In Under the Groenwood Tree, it is the wife of a tranter who

67 Evelyn Hardy, ed., Thomes Hardy's Notebooks (New Yorks St. Martin's Press, 1955), p. 30. Hereafter cited as Notebooks.

68 Iffe, p. 120. 
advises Fancy Day that it is best to say "IIs to be, and here goesl" "Iwill carry a body through it all..." (UGT, p. 196). Generally, the zustios follow the roll of the seasons and the ups-and-downs of life. spything which is "dissociated from these normal sequences" of the "regular terrestrial roll" is "foreign to local knowledge"(W, p. 53). The general attitude of the rustic characters seems to be the curious mechanical regularity of country people in the face of hopelessness..." (W, po. 144); as victims of Time, they seem "always doomed to sacrifice desire to: obligation"(W, p. 174). The limits of their aspirations is "conterminous with the margin" of the community. As the matics of Egdon Heath obserred when CIym Yeobright proposed his idea of a school to broaden the horizons of the heath natives, "for ny part, I think he had better mind his business"(RN, p. 202). Hardy's rustics are the widest spread example of passivity in all facets of Iife in the novels.

Passivity is not always a matter of rustic Ignorance, poverty, or prejudice. Tess Durbeyfield had been to school through the sixth form. She was sensitive and seemingly intelligent. She was marked with an extreme passivity, as seen in an early view of Tess the day of the "club-walking," a May Day dance. The girls danced without male partners unt1] Angel Clare came by. After dancing with several of the girls, Angel left but not without flrst noticing Tess with whom he had not danced, "owing to her backwardness" (Tess, p. 16). Tess's backwardness may be taken as shyness or modesty. More accurately, Tess's modesty and shyness were symptoms of her mother's family background as "waiters on Providence."

Tess's "beckwardness" came to be a definite passivity in the face 
of adversity. When the family horse was killed, Tess accepted the forl guilt. Subsequently, she accepted the full responsibility for the family's welfare and went to the Slopes, the D'Urberville farm, in an attempt to aid her family. Her passivity in the company of Alec DiUrberville led to her being raped. When Angel later rejected Tess because of the rape, Tess accepted the separation as her just punishment (Tess, p. 308). Later, Tess went to Flintcomb-Ash farm and accepted the harshness of its life. When she finally decided to see Angel's parents for belp, she overheard Angel's two brothers talking and, accepting their judgment of her, returned to Flintcomb-Ash and her suffering without visiting the parents who, it is made clear, would have helped her. When Angel returned from South America, he found Tess living with Alec DiUrberville in furfillment of her reassumed responsibility for her family's welfare. Her killing Alec was the final definItive assumption of Angel's guilt for his unjust violation of her innocence which violation was a reaction to Alec's guilt. Tess accepted the final sacrifice to social conventions by hanging.

As Roy Morrell writes, Hardy shows that often "man fails through neglecting chances of success. "69 The reader is reminded at least three times (twice in Chapter 36, pp. 308, 311-12; and again in Chapter 37, p. 324) that Tess could have perhaps persuaded Angel to accept their situation through the use of tears or her "exceptional physical nature." She remained passive. The result of her passiveness was, for Tess, one experlence of suffering after another-the rape, an unfortunate child,

69 Morrell, p. 88. 
a ruined marriage, harsh farmwork, her denegration as Alec's mistress, and her death.

Giles Winterborne in The Woodlanders is passive through severe self-restraint rather than through impulse as with Tess. Giles had an "imperturbable poise" which came from "a somewhat rare power in himthat of keeping not only judgment but emotion suspended in difficult cases." He did not feel inordinately proud because he did not regard his inner self spectacularly ( $\underline{W}, \mathrm{p} .37)$. Giles did not let incidents (the loss of his leaseholds; the loss of Grace Melbury, his loved one) affect his outward conduct (W, g. 112). After one outburst to Felice Charmond, Giles kept his feelings entirely to himself. When Giles' love-wound was reopened, he preserved his calm. When Giles first heard about George Melbury's plans for getting a divorce for Grace, "a subdued tremurousness about the mouth was all the response that Winterborne made..." (W, p. 327). Wo act promptly as Melbury desired him to act seemed, Indeed, scarcely wise, because of the uncertainty of events" (W, p. 334). Giles' conscience forbade him to lead Grace Into a pitfall for her happiness.

It was these virtues of resignation and acquiescence which gave Giles "a certain laxity" after his double loss, leaving him "lying on his elbow under a tree, with a cynical gaze at surrounding objects" (W, p. 206). Giles felt "that the fates were against him;" that "Fate, it seemed would have it this way, and there was nothing to do but to acquiesce" ( $W$, p. 130). Giles had a character made of a purity of nature, a freedom from the grosser passions, and a scrupulous delicacy which brought him to a "strange self-sacrifice"(W, p. 379). Giles! 
severe self-restraint, his acquiescence, and his passivity in loss and other difficult cases brought him fatal iliness. Had Giles been more active in his relations to Grace early in the novel, he might have also spared much of the suffering of her marrlage to Fitzplers. Had Giles been active enough to peruse his leasehold papers sooner, he might not have lost the leaseholds, and spared hinself, as well as Grace, much suffering. Giles' passivity in the face of the reverses of supposed Fate was largely responsible for suffering in three lives.

The problems of the extremes of self-assertion and self-restraint are not Iinited to the present moment in the novels. In conjunction with the present moment, there is what Perry Melsel calls whe Return of the Repressed;" a reintroduction into the present of past experiences which a character has often tried to escape. 70 The convergence of previous maments of passion, intellectuality, or passivity, acting as influences on the present situation, serves to limit the extent to which disastrous consequences may be avolded. In "the great web of human doIngs, " the past is very much a part of the present. To constantly bring the past into the present, Hardy uses settings like Casterbridge, fwll of relics and history; allusions to historical and mythic figures Iike Cain, Hercules, Noah, Venus, Satan, Jeremiah, Judas Iscariot, Samson, and St. John; and former events, actions, and decisions in the Iives of the characters.

70 Perry Melsel, Thomas Hardy: The Return of the Repressed: Study of the Major Fletion (New Haven: Yale University Press, 1972). Ses also Chapter I, pp. 12-14 above for the introductory discussion of recurrances of past events. 
Fancy Day remembered the secret which she will never tell Diak Dewy, her husband, because the secret might ruin her marriage. Troy returned to claim Bathsheba, causing her to suffer shock and Boldwood to shoot him and to go to jall. Fanny Robin returned to haunt Troy and to begin the agonies which end in his death. Wildeve and Eustacia's love affair returned several times to bring suffering to Thomasin, Mrs. Yeobright, and Clym. The furmity woman appeared in Casterbridge to renew Henchard's horror over the sale of his wife. Newson returned to find Hlizabeth-Jane, leaving Henchard in the misery of isolation and loneliness. The childhood encounter between Felice Charmond and Dr. Fitzplers surfaced to bring suffering to Grace, Giles, Mr. Melbury, and Felice. It becomes evident from the catalogue of past experiences recurring in the lives of the characters to what extent other persons In an individual's environment can affect suffering in life,

People affect each other not only in person. Through the agency of social institutions and conventions, which form a part of the individual's psychic enviromment, suffering is transmitted from other people Into individual lives. Felice Charmond cried out against the terrible insistencies of society" complaining,

how severe they are, and cold, and inexorable-ghastly towards those who are made of wax and not of stone.... a stab for this exror, and a stab for that-correctives: and regulations pretendly fremed that society may tend to perfection.... (W, p. 237)

Sue Bridehead questioned in like manner, what is the use of thinking of laws and ordinances,.... If they make you miserable...?" (Jude, p. 268).

The misery caused by marriage laws and conventional soctal attitudes towards marriage is nowhere more evident than in the lives of sue 
Bridehead and Jude Fawley who were each married to partners who differed greatis in temperament. The scom for "Justice" at the end of Tess of the DiUrbervilles is not so appalling because Tess killed a man, but because the very act which finally released her to partake in charity and freedom, especially freedom from self-recrimination, is the act for which society demands her death rather than the act which brings her Iffe. Society is supposed to promote the curtivation of man.71 Too often In Hardy's novels, it seems that laws and conventions are the result of a confusion of conformity and uniformity for the good and the ethical. Acquiescence and passivity in the form of imitation of the dictates of such mistaken laws and conventions are a way of continuing the injustices which bring suffering, even unto the innocent.

The processes of society seem to have gone awry not only for Tess, Sue, and Jude, but for Clym Yeobright as well. Working for a diamond merchant in Paris, serving the highly cultivated, Clym perceived that his business "was the idlest, vainest, most effeminate business that ever a man could be put to"(RN, p. 202). The societal conventions which condemed Tess to the gallows and brought Jude and Sue so much misery, made Clym feel impotent as an Individual in much the same way as Felice folt frastrated. So if social imitation does not bring specific suffering, it may bring frustration and impotence; the subjugation of the individual to the whole and the exceptional to the average. 72

Society made laws, but has not had a second intention and

71 Hixcley, p. 43.

72 orel, p. 127. 
excoution to eliminate evils and defects. 73 Grace Melbury's situation In The Woodlanders stands out as an example of this kind of soctetal faliure. Grace cried, "cultivation has only brought me inconveniences and troubles!" Grace's educational and social attainments, which rofined her into "something quite different" from the Hintock folk, allenated her from any effective contact with the world. She was too refined for Hintock, yet her background disenabled her to move readily into society.

Her fafled marriage taught Grace that exceptional attainments and base aspects of humanity can co-exist in one person. She felt revulsion for attaiments. Giles Winterborne's death forced on Grace the realization of thow little acquirements and culture welgh beside sterling personal character" (W, p. 404). Grace had become an

impressionable creature, who combined modern nerves with primitive feelings, and was doomed by such co-existence to be numbered among the distressed, and to take her scourgings to their extremity. (W, p. 358)

Education and cultivation had given Grace an "intense consciousness," yet she retained her "active emotions." Caught between two worlds, she was unable to go forwards or to go back. As Matthew Arnold wrote in Stanzas from the Grande Chartreuse, she was "Wandering between two worlds, one dead,/ The other powerless to be born"(I1. 85-86).

To remain passive and to acquiesce to the social processes and conventions can, then, be as painfur as acquiescing to the natural processes. As long as the education which society offers does "little to

73 Life, pp. $148-49$. 
modify human impulses, ${ }^{174}$ as in the cases of Fltzpiers, Sue, Angel, Troy, and Eustacia, society cannot do more than try to regulate behavior on general principles and so commit injustices which lead to suffering. However, society is not an autonomous being, rather it is the aggragate of individuals who either support or acquiesce to the conventions, laws, and processes which are propounded in the name of society and the commonwealth. Consequently, any suffering which society contributes to human lives is just as attributable to human caluses as the individually caused suffering which may come from extreme passions or extreme intellectuality. All of the causes of suffering investigated in this chæter-extreme self-assertion in passions and intellect, extreme selfrestraint in passivity or social inftation-are, then, a result of human doings and ought to be subject to human control, if man has the will to eliminate, as much as possible, the human causes of suffering. In Hardy's novels, does man have the will, does he have the capability to will to alter the conditions in his existence which through his own doings cause suffering? This question forms the basis for the discussion of human will in the next chapter.

74 orel, p. 124 . 


\section{CHAPTER: III}

\section{HUMAN WIIJ}

Recognizing the multitude of possible sources of suffering, it seemed to Hardy that the possibilities for human will to influence man's condition are limited. Hardy observed that "the will of man is... neither wholly free nor wholiy unfree."76 Considering the influence of an Individual's own Iimitations, the Iimitations imposed by the influence of others, and the influence of the past in an Individual's Iife, is there a basis for believing that within the world of Hardy's novels human wiIl could effectively influence the course of human doings and man's condition?

To effectively answer this nettlesome question wich seems to be the implied focus of much of the critical controversy over determinism, pessimism, fatalism, and human capabilities in Hardy's novels, it seems. appropriate to begin with some critical statements which, even though often couched in the nests of negative attitudes towards human potential in Hardy's novels, would seem to indicate that human will does have scme powers. Then, turning to the novels in question, a look at the results of some characters' consciousness of another's sufferings will reveal how human sympathy, Iinked with that consclousness, can motivate certain characters to try to alter the conditions which have caused or may cause suffering, and thus seem to indicate that there are

\section{Iffe, p. 335.}


possibilities for the human will to influence human doings and man's condition.

When one turns to the criticism which has been published about Hardy's works, the imnediate impression is that many critics see Hardy's writings as pessimistic, fatalistic, or deterministic. At the same time, very few critics are able, finally, to dens that humans are not so trapped as the philosophical tag-words would suggest. The general critical reticence to see man as fully a sport of Hardy's fictive universe may be only the critics' personal hope of at least a modicum of freedom for men showing through what is regarded as otherwise dark and brooding inevitability. Whatever the reasons for seeing at least $\mathrm{ta}_{\mathrm{a}}$ pinhole of lightn77 in the "darkling plainn"78 of Hardy's fiction, no critic denies that humans are the focus of Hardy's concern in the universe of his fiction. 79

Robert B. Heilman suggests that "Hardy treats his characters far less as victims than as moral beings whose histories are congruent with their natures.... n $^{80}$ J. O. Batley's analysis of The Return of the Native sees the characters not as victims of fate, rather as victims of themselves. 81 Donald A. Dike claims that while Hardy sees man as

77 Follett, p. 131.

78 Harrey C. Webster, On a Darkling Plain: The Art and Thought of Thomes Hardy (Chicago: University of Chicago Press, 1947).

79 Wagenknecht, p. 548.

80 Robert B. Hellman, "Hardy's 'Mayor' and the Problem of Intention, " Criticism, 5 (1963), 199-213.

81 J. 0. Bailey, "Temperament as Motive in The Return of the Native, " English Flation in Transition, 5 (1962), $21-29$. 
incapable of changing his character, man can control his character. 82 Only when the characters do not attempt to ward off disester are they defeated, suggests Duane Edwards. ${ }^{83}$ Roy Morrell sees that in Hardy's novels man fails only because he neglects the opportunities for success. 84

Despite a belief that Hardy subscribes to a natural determinism, John Holloway can still see that "the potentialities of change are in the people. 185 other critics see man's potentialities in the form of his consciousness. George S. Fayan sees experience as the materials of a consciousness which can be used for forming decisions and destinies. 86 Roland A. Duerksen claims that Hardy agrees with Shelley that "there must be a 'consciousness' and an effort by mankind if amelioration is to be expected. 187 . Bert G. Hornback seems to put the effort and the consciousness togethex when he claims that for Hardy "will as consciousness furfills man. "188 Consciousness of life's suffering becomes the basis for action. Emest Brennecke writes that "the basis of all

82 Donald A. Dike, "A Modern Oedipus: The Mavor of Casterbridge," Essays in Criticism, 2 (1952), 169-79.

83 Duane Edwards, "Chance in Hardy's Flction," Midwest Quarterly, 11 (1970), 427-41.

84 Morrell, p. 88.

85 Holloway, The Victorian Sage, p. 250.

86 George Slemers Fayan, Jr., Mhardy's The Woodlanders: Inwardness and Memory," Studies In English Literature, 1 (1964), 81-100.

87 Roland A. Duerksen, Shelleyan Ideas in Victorian Literature (The Hague: Mouton and Company, 1966), p. 165.

88 Hornback, p. 8. 
willing is pain, need, and deficiency" in Hardy's universe.89 H. I. Weatherby sees will as Hardy's Iife. force. 90

Frederiek Pilkington observes, "All is not gloom in the Hardy outloak for despite the waywardness of Wessex people, faith in human endeavor is retained...."191 Barry N. Schwartz sees Jude the Obscure as a celiebretion of human endeavor. 92 Even though Bonamy Dobree sees Hardy's characters as largely controlled, he does admit that "in at least three novels the events seem to flow from human will. 193 Seeing Hardy as having embroiled his characters in a determinism which was derived from Darwinism, Perry Meisel can claim that the small, insignificant individual's response to his environment is the key to the movement of I1fe.94 John Holloway sees that if man moves with events rather than against them, "human choice can exert some influence at least on the course of things....195 Duane Edwards is more positive, believing that chance can be affected by humen intention or imprudences. J. Hillis Miller argues that it is through willing, feeling, doing that

89 Ernest Brennecke, Jr., Thomas Hardy's Universe: A Study of a Poet's Mind (1926; rpt. Now York: RusseII and Russell, 1966), p. 130 .

$90 \mathrm{H}$. L. Weatherby, "0ld-Fashioned Gods: Inlot on Lawrence and Haxdy," Sewanee Review, 75 (1967), 301-16.

91 Frederick Pilkington, "Religion in Hardy's Novels," Contemporary Review, 188 (1955), 31-35.

92 Barry N. Schwartz, "Jude the Obscure in the Age of Anxiety," Studies in English Itterature, 10 (1970), 793-804.

93 Dobree, p. 32; Dobreo's italics.

94 Meisel, p. 17.

95 Holloway, The Victorian Sage, p. 281. 
man "takes part in the endless physical changes of the world.... "96 Mbert Pettigrew Miliott, who belleves in fatalism in Hardy's works, sees, all the same, that "convention can be directed by enlightenment;" and that "society can outgrow destructire morality if it will.... 197 Few critics seem to be as hoperil as the Iines from Prometheus Unbound which Hardy double-underlined in his copy of Shelleys

To love, and bear; to hope till Hope creates From its own wreck the thing it contemplates. 98

Fow critics are as positive as Roy Morrell who believes that those characters who decide to act could avoid suffering if they assure the fulfillment of their intentions because while "anything could happen,... what did happen could change." 99 Most critics, however, even some who are convinced that Hardy believed in fatalism, pessimism, or determinlam, seem to see at least a modicum of potential for man to exercise his choice and to influence to some extent his enviroment. It is necessary to look to the novels now to see human will, motivated by symathy and loving-kindness learned through suffering, being exercised.

If man has a potential to influence the course of things, then Grace Melbury's state of "intense conciousness" and "primitive feelings" would seem to be a paradigm of what man may and should become. Despite her suffering which is basically a result of the wayrardness of

96 Joseph Hillis Miller, Thomas Hardy: Distance and Desire (Cambridge, Mass.: Harvard University Press, 1970), p. 18.

97 EIllot, pp. 103, 105.

98 Phyllis Bartlett, "Hardy's Shelley," Reats-Sheller Journat, 4 (1955), 15-29.

99 Morrell, p. xd. 
the human community in removing its defects and evils, Grace appears to be for Hardy, as for her father, the "worldaly hope;" a distinction she does not want because of its contingencies which eventually brought her suffering and isolation ( $\mathrm{W}, \mathrm{p}, 104$ ). It is, however, only through the kind of consciousness which Grace had coupled with her primitive sympathy that the "Golden Rule" and simflar Ideas will advance into the conscience of man as a guideline for actions and decisions. As the "great network" of the whole united corporeal human race becomes more Intensely conscious of the suffering of its parts, the "Golden Rulen ascends as a mode of ethical, social behavior. The consciousness of suffering comes through both the individual's own suffering and a growing awareness of others' suffering. Suffering becomes the basis for an ever anding consciousness which, evolving into conscience, becomes the motivation of the human will to express sympathy and lovingkindness. Hardy believed that with a greater consciousness of suffering and its causes, a greater sympathy would also arise, 100

In the novels, a consciousness of suffering produces several different responses. In Grace Melbury's situation, her realization of Giles' suffering and sacrifice led her to a remorse for her inconsidem ateness. Bathsheba Everdene, at the end of Far from the Kadding Crowd, had learned the danger of sudden erratic impulses. Having suffered herself from her impulsive marriage to Troy and having seen the suffering which Fanny Robin experienced and the suffering which her flirtatious impulsiveness incited in Boldwood, Bathshoba was less quick to 100 Iffe, p. $335 .^{\prime}$ 
respond lightly. Her intensified consciousness of suffering made her wary. Similarly, Giles Winterborme "maintained his abeyant mood not from want of reciprocity, but from a taciturn hesitancy taught by life as be know it" (W, p. 328).

In Jude the Obscure, Richard Phillotson realized how seriousiy Sue was suffering and acted sympathetically. His recognition of her suffering prompted him to release and, later, to divorce her. Through Sue he learned "that it is wrong to so torture a fellow creature..." (Jude, p. 277). Through his own suffering in a South American jungle, and through his gradual realization of the misery his actions brought on Tess, Angel Clare learned to judge a person less for their deeds than for the will behind the deeds (Tess, p. 473). Similarly, Michael Henchard realized through the process of his rulnation, suffering, and eventual isolation that his life was like Cain's and that because he ought to have acted more sympathetically and considerately than he did, he deserved his punishment (MC, p. 361).

Suffering can give a character more than remorse, wariness, abeyance, or symathetic feelings and actions. Suffering can also make a character aware of the need for the human will to adjust and compromise, In The Return of the Native, Clym Yeobright's consciousness of other people's interests and desires was borne out of his mother's death, his wife's attempted escape and resulting death, his own physical loss of vision, and the Heath natives' reluctance to accept a school which would attempt to ralse them "to serene comprehensiveness without going through the process of enriching themselves..." ( $\mathrm{RN}$, p. 204). Clym learned from these experiences of suffering and resistance to alter his 
aspirations to the needs of the situation. He became an itinerant openafr preacher, a role which was more nearly adapted to the needs and the interests of the Heath dwellers than his school plan.

In Far from the Madding Crowd, Gabriel Oak Iost his sheep. He was momentarily in a stupor, but recovering, he was first thankfll that he was not married. His thankfulness is the first indication that he will not be overcome and so will try to make the best of his disaster. As a first step, he settled his debts and then, adjusting his aspirations, searched for a job as a hired shepherd. At Bathsheba's estate, he was hired and thrown into close relations with the woman he loved but could not marry. Even though his juxtaposition with Bathsheba caused him emotional distress, he maintained control, and worked as well as he could for her. He advised Bathsheba occasionally in her relations with Boldwood and Troy. This advice was on attempt to act on his consciousness and to influence the situation for the better. Whatever emergency arose--the rick fire, the bloated sheep, the storm, Fanny RobIn's funeral-Gabriel was able because of his ability to adjust to the demand of the moment, learned through his own losses, to produce the best possible results in the circumstances; his experience and his loving-kindness helped him to adept his will to the situation.

A consclousness of the sources of suffering was also the basis of another character's attempts to influence situations for the better. D1ggory Venn, who loved Thomasin Yeobright, Clym's cousin, but had been rejected as her suitor, tried to help in whatever ways he could to prom mote and to protect Thomasin's happiness, even when she decided to marry Wildeve in The Return of the Native. Venn gambled with Wildeve to win 
back the money sent bys. Yeobright for Thomasin's own use. When Wildeve continued to visit Eustacia Vye, his former Iover, Venn intercepted him, giving him warning signs against treacherous conduct. Even though Venn could not marry Thomasin, he readjusted his energies to try to preserve Thomasin's marriage and happiness, rather than allowing sorrow for his loss to sour the sympathy and loving-kindness he felt for Thomasin. Not only with regard to Thomasin, but for other characters too did Venn try to help as much as he could. On the night of Bustacia's attempted flight from the Heath and her husband, Venn rescued CIym and attempted to rescue Wildeve and Eustacia from the weir. Venn asserted his will to try to aid others and to make the best of the situation as much as possible through his sympathy and loving-kindness wich gave him a desire to try to prevent suffering at its causes. In addition to the realm of human relations, suffering may be alleviated in other aspects of life through an application of human will actuated by sympathy and Ioving-kindness. Donald Farfrae in The Mayor of Casterbridge had a sympathy which prompted him towards the best possible consumation. Farfrae used scientific knowledge and modernized methods to effect changes for the better in Casterbridge. Donald reconstituted ruined grain. He placed the books and dealings of Henchard's business on equable and efficient terms. Later, as a grain dealer in his own business, Donald introduced a mechanical seeder to ease the work of seeding as well as to increase efficiency. When it was time for a fair in Casterbridge, Farfrae considered the possibility of inclement weather and set up his festivities under cover, thus assuring an enjoyable holiday. Farfrae was equally sympathetic in his direct relations 
with people. He insisted that AbeI Whittio not be made to suffer the cmbarrassment of driving through the streets half-dressed. When Donald opened his orm grain trade after Henchard fired him, Donald refused to deal with Henchard's most recent and Iucrative customers. After Henchard's financial ruin, Farfrae bought Henchard's house and furnishIngs and gave some of the furnlshings to Michael because maybe it's worth more to you than it is to me," being "endeared to ye by associations, or particulariy suited to your use"(NC, p. 262). Farfrae was able to adjust, to compromise, and so to alleviate suffering through sclentific knowledge and loving-kindness, and he used his will to effect the best in the situation. 101

"Soientific knowledge" of suffering and its causes, of the needs and wants of others, and of the most efficlent and equable methods forms the basis for actions of the will. Suffering, their own and others', con give characters a "scientific knowledge" of the causes of suffering and of the actions which a situstion might require for the best possible consumation. It is a knowledge, based on the results of experience, from which the characters seemed to learn when to use their wills for self-assertion, as with Farfrae's introduction of the mechanical seeder, or Phillotson's release of Sue; and when to use their wills for selfrestraint, as with Clym's limiting of his aspirations, or Giles' taciturn hesitancy when he heard about Grace's plan to divorce. Neither excessive self-assertion nor excessive self-restraint will work in

101 For an interesting study of Susan Henchard-the poor, weak, ignorant wife of Michael-and her manifestations of a strong will in certain situations, see Robert B. Heilman's article, "Hardy's 'Mayor' and the Problem of Intention," Criticism, 5 (1963), 199-213. 
every situation. No one, consistently applied mode of behavior seems appropriate for all of the circumstances and contingencies in the novels. There needs to be a dynamic balance between self-assertion and selfrestraint; that 1s, an adaptability which involves adjustiment and compromise according to the situation so that the best possible consummation will result. This adaptability seems to be learned from experience with suffering and appears to be the result of the human will acting through a consciousmess of suffering which can give the characters remorse, wariness, abeyance, and sympathy, but most important a motivation to bring about the best possible consumation. The best possible consumation is the key to another factor operating in Hard's novels; moriefly, evolutionary meliorism." Bvolutionary meliorism, which depends on the human will for beneficent functioning, is the topic of the next chapter. 


\section{GHAPTER IV}

\section{BOTUTIONARY MELIORISM}

Hardy describes the gradual process of the intensification of consciousness, of the expansion of sympathy, and of the leaming to adapt the assertion and the restraint of the will, leading towards the gradual betterment of man's condition, as evolutionary meliorism. In order to see cleariy what the mature and the process of evolutionary meliorism means in social terms and in terms of human passions, intellect, and relations, it seems advisable to approach the topic from several avenues. One avenue is to look to T. H. Huxleyt's essay "Evolution and Ethics." This is not to say that Hardy read Huxiey's essay, though he could have; and it is certainly not possible to say that Hardy followed Huxiey's essay when writing his novels. 102 There are also some seemingly significant differences. For the most part, as far as evolutionary meliorism may be seen as topically present in Hardy's novels, the tendency of the novels is parallel to Huxley's essay. The second avenue is, then, to review the tendency of the novels In terms of the outcomes which seem to evolve from the series of circumstances. In addition to the overall tendency of the novels, there seems to be support from an element of the narrative technique for another aspect of the process of evolutionary meliorism. With the tendency of

102 Huxley's essay was first published in 1893. While Hardy Iived until 1928, all of the major novels had been published, except Jude the Obscure, by 1893. 
the process to eliminate the undesirable units of human society in the novels, those units which are responsible for extensive suffering, there goes the apprehension that some of the variety of human life mas be sacrificed and made extinct through ethical selection. To reveal this background apprehension and apparent attendant sadness, it will be necessary to look critically at the function of point of view in the novels.

In his essay "Bvolution and Ethics," T. H. Huxiey discusses the nature of evolution in society and explains how ovolution can gmelforate man's condition. In the struggle for existence, man is aided by his instinct for self-assertion. ${ }^{103}$ The fund of energy man derives from self-assertion, coupled with a superior intellect, is "competent to Influence and modify the cosmic process"(p. 84). Man's energy and Intellect have produced combinations of material bodies, states of art, thich are impossible in the state of nature (p. 10). In the development of a state of art, men cultivate themselves also. The "gardening of man" is the creation of conditions which "facilitate the free expansion of the innate faculties of a citizen [wich are] consistent with the general good"(p. 43). In relation to society, the "horticultural process" becomes the "ethical process." Social progress, the measure of man's success in adopting the ethicel process and developing a state of art, depends upon man checking the cosmic process and promoting the survival of those persons who are ethically the best (p. 81).

103 Hoxiley, pp. 51-52. Unexplained page numbers in the text of this brief description of Huxcley's ideas refer to Evolution and Ethics and Other Essazs (see p. 3, note 33 above). 
The organic necessities of society are mutual affection, symathy, and initation (p. 28). The ethical process becomes an evolution of the feelings of mutual affection, sympathy, and imftation into the human conscience (p. 30). As the ethical process refines civilization towards social perfection and worth, self-assertion becomes a defect. A man may use his self-assertion against his neighbor. Soctal progress increases the importance of sympathy. To curtail self-assertion, ethical man develops laws to "restrain the self-assertion of each man within the limits required for the maintenance of peace" (p. 18). While self-assertion helps man to maintain society against the cosmic process, self-restraint helps man to maintain soclety against Itself. The evoIution of society is a process in which

the motive of the drama of human life is the necessity, latd upon every man who comes into the world, of discovering the meen between self-assertion and self-restraint suited to his character and his circumstances. ( $p$. vili)

In marked similarity to Huxley's essay, Hardy's major novels show that those self-essertive characters who display strongly non-adaptive, non-ethical tendencies do not generally survive their experiences. If society does not eliminate these characters, in part what happens to Henchard, they are just as likely to aggravate their own destruction ultimately. The tendency in the novels is towards some degree of social or cultural improvement. Those characters who are ethically better within the world of their novel tend to survive, although not without some suffering.

In Far from the Madding Crowd, for example, Sergeant Troy was Incapable of adapting himself to the needs of anyone or anything beyond 
himself. His ethical unadaptability clashed with Boldwood's passionate distraction, an inability to adapt to Bathsheba's marriage to Iroy, resulting in Troy's death and Boldwood's confinement. The adjustable Oak and the conscious Bathsheba survived. Likewlise, Bustacia Vye's undeterable pursuit of higher passions in The Return of the Native drove her to attempt to flee Egdon Heath in any way possible. She could not adapt to Iife on the Heath or to its customs. The adjusted, compromism Ing characters, Clym and Venn, did survive.

In another, yet similar vein, Henchard's unyielding desire to possess the situation and the people around hin in The Mavor of Casterbridge made him incapablo of adapting to uncertain contingencies, partial successes, or roverses. He was left in isolation. Through isolation be was removed from the society so that an ethically better man, Farfrae, could replace him. Another aspect of passionate unadaptability which is eliminated is Fellce Charmond, the "passion Incarnate" in The Woodlanders, who could not adapt her feelings and sensibilities either to the Hintock woodlands or to the restrictions intended to perfect society. Her unadaptability disturbed Grace and Fitzpiers.' marrlage and left a rejected lover who destroyed her. The ethically better Grace and a seemingly more sympathetic and ostensibly repentent Fitzpiers survived her. Similar to Felice's unadaptability is Alec DiUrbervilie's singlominded pursuit of passion which prevented him from directing his energles effectively into any channel other than chasing Tess. This unadaptabllity of aims placed him in a position in wich he aggravated his own death. The ethical convert, Angel Clare, survived. The Angel Clare who rejected Tess and sent her through much 
ouffering was eliminated in the South merican jungle. Thus, Hardy's novels have an overall tendency towards evolving a better himanity.

Thts general tendency in the novels results in the ethical process of evolutionary meliorism tending to effect average emotions and longrange views which allow better and easier adaptation. As sympathy becomes more importent to society, the extremes of self-assertion, emotional and intellectual, which cause suffering, and the extremes of self-restraint which neither prevent nor avoid suffering, need to be attenuated. Since the results of the extremes might first appear later rather than immediately, as often occurs in Hardy's novels, one needs to have a long-range view of possible consequences when one surveys the Worst." Long-range views, guided by sympathy, reduce necessarily the range of self-assertion and self-restraint.

Donald Farfrae exhibited a long view when be bought grain cautiously wille Henchard bought, and the farmers sold, recklessly. The result of Farfrae's caution was that he prospered from the umpredictable harvest while Henchard and the farmers placed themselves in penury. The average emotions upon which Farfrae acted allowed him to accept the death of his wife Iucetta without paralyzing grief. The social result of Farfrae's Iong views and average emotions was that the farmers who sold, and later his workers, suffered less from Farfrae's dealings. Farfrae's ascendency in Casterbridge becomes a foreshortened evolution of society away from extreme self-assertion and suffering towards a balance of self-assertion and self-restraint "consistent with the genoral good."

Arother of the effects of evolutionary meliorism took place in 
the South American jungle where Angel Clare learned to temper his strict adherance to general principles according to the particular instance. What arrested him now as of value in Iife was less its beauty than its pathos." "The beauty or ugliness of a character lay not only in its achievements, but in.its aims and impulses..."(Tess, p. 434). Angel learned to judge constructively rather than biographically (Tess, p. 473). The sudden alteration in Angel's outlook is the sort of alteration which evolutionary meliorism is expected to induce gradualiy in the human race. 104

However, the difficulty of man's condition is not always conducive to easy cholces, making a general process of the extinction of apparently unethical characters arbitrary and perhaps unsympathetic. Besides the multitude of possible influences in any situation which may make the ascription of the source of the cause of suffering difficult, there are times when some things are both good and antagonistic. 105 As Clym saw in The Return of the Native, "three antagonistic growths had to be kept alives his mother's trust in him, his plan for becoming a teacher, and Eustacia's happiness,....two of the three was as many as he could hope to preserve"(RN, p. 237). As a further complication, there is also often sorriness under the grandest things and grandeur under the sorrlest. 106 As often happens, the substance of a situation is judged and

104 cf. Hormback, p. 24; Hardy is concermed with finding and showing man's potential." Hornback observes that Hardy intensifies the World and Time in the novels to make them a testing ground.

$$
\begin{aligned}
& 105 \text { Iife, p. } 282 . \\
& 106 \text { Iife, p. } 171 .
\end{aligned}
$$


retained or rejected on an estimate of the superficies (ㅁ, p. 154), when perhaps a more sympathetic and ethical judgment ought to consider all aspects.

In Inder the Groenwood Tree, the Mellstock quire was to be replaced by an organist. Parson Maybold surmarized the situation:

I gee that violins are good, and that an organ is good; and when we introduce the organ it will not be that fiddles were bad, but that an organ was better. (UCS, p. 87)

I consider it more proper and feel justified in endeavoring to introduce it.... (UGT, p. 85)

The Parson and the Quire agreed to a compromise date between an irmediate change and a change in the distant future which the Quire requested. In this situation, it was impossible to use both good forms of music in the church, and a temporary compromise between the two antagonistic forms was enacted, keeping the general unhappiness to a minimum yet failing to satisfactorily sustain all that was good.

Fustacia Vye is an example of a mixture of grandeur and sorriness.

Eustacia Vye was the raw material of a divinity. On Olympus she would have done well with little preparation. She had the passions and instincts which make a model goddess, that is those which make not quite a model woman. Had it been possible for the earth and mankind to be entirely in her grasp for a while, had she handled the distaff, the spindle, and the shears at her own free will, few in the world would have noticed the change of govermment. There would have been the same inequality of lot, the same heaping up of favours here, of contumely there, the same generasity before justice, the same perpetual dilemas, the same capritious alteration of caresses and bIows that we endure now. (N, p. 75)

Thus we see her in a strange state of isolation. To have lost the godlike conceit that we may do what we will, and not to have acquired a homely zest for doing what we can, shows a grandeur of temper which cannot be objected to in the abstract, for it denotes a mind that, though disappointed, forswears compromise. But, if congenial to philosophy, it is apt to be dangerous to the commonwealth. (RN, p. 81) 
Since Eustacia was responsibie for causing suffering because of her extreme passions, her extreme behavior needed to be attenuated for the commonwealth. Yet, because the rery aspect of her nature which caused suffering had a grandeur, the reader seems to be invited to wonder if there at least ought to be a way to preserve that grandeur while avolding the related suffering. Such questionings may tend to arouse an ambivalence in the reader; emotional sympathy, jet reasoned rejection.

The alloyed nature of characters which may tend to arouse ambivaIence in the reader towards any one of the characters is supported in the novels through Hardy's control of point of view. The editorially crmiscient narrator 107 ranges over the characters and events, shortening and lengthening perspective distance, choosing which one pattern in a multiplicity of patterns to follor, ${ }^{108}$ and choosing the time and point of concentration. It is important to know not only the perspective of the narration, but the focus of attention. By changing the perspective, the distance, and the focus of the point of view, the reader's reactions to ans one character or event are complicated. It becomes difficult, in these terms, to judge with unqualified conviction. The reader seems to be put into the sort of dilemma which Parson Maybold describes:

It is often said how difficult a matter it is to act up to our convictions and please all parties. It may be said with equal truth, that it is difficult for a man of any appreciativeness to have convictions at all. (UGT, p. 87)

107 Norman Friedman, "Point of View in Fiction: The Development of a Critical Concept," PMLA, 70 (1955), 1160-84. The term is Friedman's. 108 Ifife, p. 153. 


set

When the reader notices the perspective and focus of point of view In Under the Greenwood Tree in relation to Parson Maybold, it will be noticed that only twice in the story are erents or circumstances seen from his perspective. Both times relate to his affection for Fancy Day. The first time is the first Sunday on which Fancy plays the organ in the Church. The reader Iearns of Maybold's affection for Fancy and his unsuccessful attempts to stifle the affection. The second occasion is the day after his proposal to Fancy when he writes a letter requesting an exchange of parishes. Maybold met Dick Dewy on the road to Casterbridge. The reader, having followed Maybold to this encounter, hears Dicis tell the Parson (and the reader who knows already) of his engagement and pending marriage with Fancy. By focusing the reader's attention on Maybold, the reader can feel the shock of Maybold's recognftion while feeling that events will most likely resolve well. When the reader sees Maybold shred his letter, the reader knows that Maybold has acted rightly, jet feels the sadness of Maybold's disappointment. The result for the appreciative reader is that there is a slight undercurrent of resentment for Dick as an intruder despite the fact that the reader has been struggling with Dick through the difficulties of his courtship.

Similar manfpulations of point of view in other novels make it difficult for the reader to finally condemn or praise any one character completely. Sergeant Troy, the reader feels, ought to stand condemned for his treatment of Fanny Robin and Bathsheba. Such is the manipulation of point of view that the reader feels some sympathy and even cooperation with Troy. After Fanny's death, the reader participates in 
Trog's anguish and chagrin. Troy's care of Fanny's grave is commendatory. The reader shares Troy's frustration when the down spout ruins the grave. When Troy swims in the sea, the reader struggles with Troy to escape the tide. The reader's attitude towards Troy has been completely reversed from the sword-exercise scene in which the reader sees the flash and blur of sword and arm as it overwhelms and confuses Bathsheba.

In The Mayor of Casterbridge, the reader's sympathy abides with Henchard as he slips lower into ruination while understanding that Henchard's behavior is in many ways reprehensible. Within one scene, the reader is made to feel the ridiculous yet pathetic nature of Henchard's situation. When the Royal Personage is scheduled to visit Casterbridge, Henchard requests the city council to be allowed to participate in the reception. From following Henchard's unfortunate decline, including an agonizing hour on a bridge known for suicide, the reader feels inclined to give Henchard pernission. The council refuses. The reader feels Henchard's indignation yet balks at his determination to participate to spite the council. When Henchard does greet the Royal Personage, the reader's perspective and distance is moved back to a grand-stand seat beside Elizabeth-Jane with whom the reader shares a shocked, almost horrified disbelief, while the ridiculous posture which Henchand displays strikes the reader as ludicrous. When Farfrae pushed Henchard roughly aside, the pathos of this lonely, despised, and neglected man resounds through the reader's consciousness. In effect, the point of view concentrates the reader's attention more on the contingencies and the consequences than on the fact of an 
incldent or a character (W, p. 104). Any event is only important in terms of the characters it affects. It is not so much the force of the blow which counts, "as the nature of the material that received the blow. ${ }^{109}$ The focus of the point of view in any one novel is directed towards the character who receives the greatest shock from the blow. In cases where a bIow strikes relatively equally more than one character, the focus will shift, lighting on one character and then the other, as in the scene in Far from the Madding Crowd in wich Fanny Robin's coffin is seen first by Gabriel Oak, then by Bathsheba, and then by Troy (FMC, end of Ch. 42 and Chs. 43 and 45). Such shifting of focus and, at times, distance gives the reader an appreciation of the multiplicity of contingencies and consequences any event may have and so serve to complicate any easy judgment of good and evil, right and wrong, cause and effect.

The mixture of grandeur and sorriness and the focusing of the reader's sympathy through point of view point towards some sources of sadness in Hardy's attitude towards evolution, social improvement, and the function of human wlll. In part, Hardy's sadness seems to arise from the necessity for human beings to regulate themselves through scientific knowledge. Basically, Hardy cared more for a life of emotion than a Iife based on the science of climbing. 110 Thomas Hardy was always a person with an unconscious or rather unreasoning tendency.... 111

$$
\begin{aligned}
& 109 \text { Iife, p. } 415 . \\
& 110 \text { Life, p. } 53 . \\
& 111 \text { Life, p. } 384 \text {; Hardy's Italics; seo Purdy, p. } 273 .
\end{aligned}
$$


It would be possible, he felt, that in time man might regard every object or movement, not as this or that material or motion, but as "varying proportions of pleasure and pain. "112 Appropriately, his idea of religion and the religious was "nobler feelings towards humanity and emotional goodness and greatness....." 1113

However, Hardy felt himself faced with the necessity of thaving to carmy on his life not as an emotion, but as a scientific game, $n^{114}$ It is not only that the "scientific game" must be carried on, but that the effects of the game seem to form another part of Hardy's sadness. Hardy seems to see good and bad in situations and people as well as antagonism. Hardy wants the best consummation possible, but he does not want to lose grandeur because it is alloyed with sorriness. As the ethical process ovolves in soclety, the extremes of passion, intellect, and passivity become ameliorated into average emotions and long-range views. The loss of passionate extremes which cause suffering may well entail a corresponding loss of the higher affections.

Sergeant Troy, being entirely innocent of the practice of expectation, was never disappointed. To set against this negative gain there may have been some positive losses from a certain narrowing of the higher tastes and sensations which it entailed. (FMC, p. 190) Simflarly, the result of Bathsheba's experience in Far from the Madding Growd was that she "never laughed readily now"(NC, p. 463). Bathsheba had learned to control her impulses so that they were less likely to cause suffering, but she is also less likely to enjoy so much. As Hardy

$$
\begin{aligned}
& 112 \text { Life, p. } 217 . \\
& 113 \text { Life, p. } 332 . \\
& 114 \text { Life, p. } 104 .
\end{aligned}
$$


pointed out in Chapter 2 of Tess of the DrUrbervilies, "the habit of taking long .views had reduced emotions to a monotonous average."

CIym Yeobright limited his teaching aspirations, but the results of his itinerant open-air preaching were ambiguous and unspectacular. With the lowering of aspirations, the attempt was lost to give the heath eremites knowledge of a sort which brings wisdom sather than affluence. To avold disastrous consequences which bold strokes may bring if they fail, bold strokes are not attempted. The avoidance of extremes of emotion or intellect which might bring suffering entails the lowering and limiting of higher possibilities.

The tendency of evolution through the ethical process is to ovolve, Huxcley informs us, in addition to mutual affection and sympathy, imitation Into conscience. While a society should facilitate "the free expansion of the innate faculties of the citizen...." the expansion must remain "consistent with the general good." To this end, selection towards an ideal must be enected through laws, moral precepts, and the social pressure of opinion. ${ }^{115}$ Selection towards an ideal is the mincreasing of the proportion of persons who possess [courage, industry, and co-operative intelligence 7 , and diminishing that of persons devoid of them. $n^{\text {T16 }}$ Imitation by individuar units of society of the mode of behavior which will best conduce to the survival of the ethically best is a means of social progress.

Despite his hopes for evolutionary meliorism and the lessening of 115 Huxiey, p. 82.
116 Huxcley, p. 19. 
pain, Hardy does seem to regret that the betterment of man may involve some losses of positive values. If imitation is indeed a necessary mode of behavior for the improvement of man's condition, Sue Bridehead expressed a sharp doubt about its value:

She, or he 'who lets the world, or his own portion of it, choose his plan of life for him, has no need of any other faculty than the ape-ilke one of imitation.' J.S. Mill's words....l

Phillotson replied to this woman who was always seeking new sensations with the other aspect of the argument. What do I care about J. S. Milil I only want to lead a quiet life l"(Jude, p. 269).

Hardy seems to be concerned that in the process of improving society, that there is not a corresponding and tragic loss of individuality and varlety. Sue Bridehead added to her observation, ro produce "Htman development in its richest diversity".... is to my mind far above respectability"(Jude, p. 270). In the change which replaced the MeIlstock quire with an organ, it is apparent from the Preface as well as the perspective of the novel that Hardy lamented that the Quire was replaced. The loss of the zest and the flavor of these musicians was, for Hardy, almost wholly indefensible and sad (UGT, p. vili). During the reading of The Mayor of Casterbridge, the reader senses the pathos of Henchard's decline to ruination. The sense of Henchard's utter isolation following the decline breaks over the reader nowhere more strongly than in the plaintive tone of his will and the loneliness of his death.

Michael Henchard's Will

That Elizabeth-Jane Farfrae be not told of w death, or be made to grieve on account of me. \& that I be not bury'd in consecrated ground. 
\& that no sexton be asked to toll the bell.

\& that nobody is wished to see my dead body.

\& that no mourners walk behind me at my funeral.

\& that no flours be planted on grave.

\& that no man remember me.

To this I put ny name.

Michael Henchard (MG, p. 384)

With the passing of Henchard from Casterbridge, "the rugged picturesqueness of the old method disappeared with its inconveniences "MC, p. 103). While Hardy seems to feel and wants the reader to feel a certain sadness at the passing of the "picturesque," it is also necessary that the reader understand that the "inconveniences" and the suffering must stop. Even though high aspirations and hopes and ecstatic joy may be lost in the evolution of a better world, Hardy recognized that individually "the passions ought to be proportioned as in the world itself."117 It is equaliy possible, perhaps probable, however, that evolutionary meliorism might induce variability ${ }^{118}$ rather than imitation. The foregoing examples would tend to indicate that Hardy would lean towards this position, at least emotionally, which would be a difference from Hexley's view of evolution in society. Yet, even if variability seems a less likely possibility as passions become proportioned to the world Itself, Hardy saw, too, that ecstatic joy and high aspirations could become defined differently. In The Navor of Casterbridge, ElizabethJane pointed to a new range of variabilitys an adaptation of the emotions to a proportion "as in the world Itself:"

As the lively and sparkling emotions of her early married life

117 orel, p. 127.

118 Walter Bagehot, Physics and Politics (1872; rpt. New York: Alfred A. Knopf, 1948), p. 64. 
cohered into an equable serenity, the finer movements of her nature found scope in discovering to the narrow-lived ones around her the secret (as she had once learned it) of making limited opportunities ondurable; which she deemed to consist in the curning enlargement, by a species of microscopic treatment, of those minute forms of satisfaction that offer themselves to everybody not in positive pain; which, thus handled, have much of the same inspiriting effect upon life as wider interests cursorily embraced. (MC, p. 385)

The new emphasis of the emotions has to become a concentration on intensity rather than on extensity. As Matthew Amold wrote in Stanzas from the Grande Chartrouse,

More fortunate,.... ...an age,

Which without hardness will be sage, And gev without frivolity (11, 157-60).

Until that age comes, man must recognize his suffering and use it as the motive of the will to change for the better.

Por, the difficulties of social progress are not linited to "picturesqueness" versus "inconveniences," Hizabeth-Jane's experiences had taught her about another problem in life:

Her experience had been of a kind to teach her, rightly or wrongly, that the doubtful honour of a brief transit through a sorry world hardly called for effusiveness, even when the path was suddenly irradiated at some half-way point by daybeams rich as hers. But her strong sense that neither she nor any human being deserved less than was given, did not blind her to the fact that there were others receiving less who had deserved much more. (MC, p. 385)

Hence, with the slow, gradual improvement of society and man, there can be disasters along the way. The horrendous experiences which Tess Durbeyfield had to suffer so that one individual might be improved were Indeed sad. To waste the unselfigh purity of Tess's sensibilities and impulses seems hardly worth the corresponding gain, either individually or socially. Tess's death becomes an indictment of society's wrongheaded attempts towards improvement, in addition to the obvious need 
for control of passionately and intellectualfy extreme impulses. If Tess's predicament was tragic, Jude Fawiey's was anguishing. Through his experiences with Arabella and Sue, Jude learned the delicate balance between self-restraint and self-assertion. Jude had tender feelings of altruism, not only for birds, worms, and rabbits, but for Sue and Arabella as well. When Arabella came to Jude because of her troubles, Jude responded sympathetically to Arabella's needs and cared for the child of their dissolved marriage. When Sue and Jude began to live together, Jude avoided pressing sexual relations onto her. Jude was able to readjust his aspirations for an university education and to accept the happiness of the moments he and Sue shared, as at the flower show (Jude, pp. 357-58). When the children's deaths struck a severe blow in their lires, it was Jude who was able to see that they were fighting only "against man and senseless circumstance," not against "all the anclent wrath of the Power above..." (Jude, p. 413). These "pioneers" of virtue, refined sensibilities, and innocence were sacrifliced as much ta the gradual improvement of mankind as to the general unimproved state of man and soclety.

So while the process of evolutionary meliorism may not be able to salvage the full variety of human life, and that inability is apparently a source of sadness for Hardy, any arresting or failure to promote the betterment of mankind, society, and the human condition may have far more disastrous results. Passivity, lethargy, or general unawareness mag account for the loss of individuals who, despite the great disadvantages which the present human condition places on them, overcome, at least temporarily, the obstacles to their beatitude. These heroes of 
man's struggle seem to be meant as incentives for man to work towards ovolving something better for himself in his existence in this world. 


\section{CHAPTER V}

\section{GRACE}

The cases of Giles Winterborne, Grace Melbury, Tess Durbeyfield, Sue Bridehead, and Jude Fawley indicate as strongly as any Idea or belief wich Hardy penned elsewhere, the need for mankind to work towards better conditions for man's existence. Their situations and experiences indicate that it is not only the individual excesses which cause suffering for humans, but the cumulative effect of the general terdencles of the whole "wob of human doings." As long as the "wob of human doings" deters rather than promotes evolution towards better conditions, the exasperation of the virtuous, expressed as "the coming universal wigh not to IIve"(Jude, p. 406), will remain.

In the world of Hardy's fiction, the evolution of better conditions is largely a function of loving-kindness. For mankind to improve his conditions of exlstence and to maintain that improvement, lovingkindness, working with sclentific knowledge, and performed through the human will, becomes the means towards betterment. Once a man leads his Iffe with constant reference to this mode of behavior, he achieves Individual betterment. If more of mankind becomes motivated through a growing consolousness of suffering, their own and others', to behave with loving-kindness, the gradual evolution of mankind will bo towards a general betterment inlch mas eventualis evolve into conscience so that man's natural impulses urge symathy and loving-kindness rather than 
unlimited self-assertion.

Through evolutionary meliorism, the extremes of self-restraint or of self-assertion may attenuate and merge into a balanced adaptability. Mankind may be expected to assume the patience, the steadfast lovingkindness, and the adaptability to situations of Gabriel Oak. Diggory Venn's attempts to prevent suffering may become Iinked with Donald Farfrae's sustained judgments and efficient methods. The cardinal virtues of "Self-Control, Perseverance, Wisdon, and Love..." (W, p. 167), wich Giles Winterborme displajed as honesty, goodness, tenderness, and devotion, may become a part of the conscience of man, urging his impulses to temper general principles with tenderness for the speciffc case and to judge the deed with a consideration of the will. Socleties for the relief of suffering would then become a part of a "general growth of altruism" which would tend to remove isolation and to ameliom rate man's condition. 119

What seems to have happened to these characters is a tendency for their experiences with suffering, their own and others', to evolve into behavior which arises almost instinctively, particularly in the cases of Donald Farfrae and Gabriel Oak. With little apparent effort, they seem to know what actions are right for the situation. They might be said to be in a state of existence which is analogous to the biblical state of Grace.

T. H. I. Parker traces Grace to two 0ld Testament Hebrew words. 119 Life, p. 306; Orel, pp. 74-75. 
One of the words defines Grace as loving-kindness or mercy. ${ }^{120}$ Admittedly, the blblical concept of Grace refers to the God's mercy to man. In a century which began to doubt and then to turn from Judeo-Christian religious tradition, the possibility of God's mercy to man became less tenable. The gradual deterioration of Hardy's faith in the efficacy of the Christian religion ${ }^{121}$ turned his attention from the skies towards man.

With Hardy's attention apparently focused more strongly on this world than another, he hoped for a time when the exchange of international thought, backed by a global patriotism, might bring about the selvation of the world. ${ }^{122}$ If, through the process of evolution such a condition might arise, the beginnings of which are apparent in the fact of a consctausness in higher animals which is not apparently a part of the vaster whole of the universe, then it might also be possible, since It is possible to belleve that what takes place in a part may spread to the whole, that the Universal Will could become conscious, sympathetic, and an ald to the betternent of man's existence. In that condition, the Unfversal will would shed loving-kindness and mercy on mankind, thus evolving a new, yet similar concept of Grace.

When such a state of Grace might be expected to arise is a

120 T. H. I. Parker, "Grace," Baker's Dictionary of Theology, ed. Everett F. Harrison, et al. (Grand Rapids, Mich.: Baker Book House, 1960), pp. 257-58, CP. F. I. Cross, ed., The Oxford Dictionery of the Ghristian Church (London: Oxford University Press, 1958), pp. 576-77, whtch indicates, along with a historical survey of the various doctrines of Grace, that Grace 1s essential to performing good works.

121 Notebooks, p. 77.

122 Iffe, p. 419. 
difficult question. In many ways, Jude Fawley exemplifies individual botterment, as do Gabriel Oak, Diggory Venn, and Donald Farfrae; a condition which might be seen as analogous to Grace. Tess Durbeyfleld and Giles Winterborne approach close and seem to be held back only by an excess of self-restraint, but their feelings and unselfishness are right. Since the "great web of human doings" is a part of the family of all organic Iffe, and since man's will is a part of the Universal will, it seems appropriate to assume that thuman affairs illustrate the same necessitated slowness as the affairs of Nature."123 George Wing observes of Hardy that "in his creative work the meliorism seems to be a long time in evolving..... $n^{124}$

For Hardy, the possibility of man using his experience to evolve better conditions was intrinsic. Had the teachings of experience grown cumulatively with the age of the world, we should have been ere now as great as God." ${ }^{125}$ He recognized, too, that nthe remedy tarries long." In a nation which could develop so much politically and economIcally as England did during his lifetime, Hardy saw that there was not an equal advancement of real civilization. People were not more humane, and disinterested kindness was less in his later years than in his youth. ${ }^{126}$ With the material advances of Victorian England, there were also advances in knowledge-under the leadership of Lyell, Darwin,

123 Holloway, The V1ctorian Sage, p. 269.

124 Ceorge Douglas Wing, Handy (Edinburgh: Oliver and Boyd, 1968), p. 109; Wing's Italics.

125 Iife, p. 55.

126 Life, pp. 405-06. 
Huxley, Marx and Engels, Spencer, and others-but without the advancement of real civilization, Hardy saw "how very far conduct lags behind the knowledge that should really guide it. 1127

The decline of humane and disinterested kindness seems to indicate a failure of human altruism; an acquiescence of human will to self-assertion rather than a directing of the will towards loving-kindness. Because each new child born will bring an instinct for unlimited selfassertion into the world, ${ }^{128}$ the evolution towards the new concept of Grace will necessarily be slow and faltering. Even if man or mankind approaches a condition apparently like Grace, the unforeseen may still cause problems which may bring suffering. Despite her general contentment and her ability to enjoy small moments of pleasure intensely, EnIzabeth-Jane believed still in the possibility of unforeseen suffering while wondering at its persistence (MC, p. 386). Jude Fawley approached an individual condition which approximated Grace, but the unforeseen deaths of the children brought frustration and anguish into his life again, and with them, death.

In order to better himself, it becomes necessary for man to know as fully as possible the possible influences and effects which any decision or action may involve. Ideally, man would need to be omniscient. Since man is neither omniscient nor is likely to become omniscient, it is necessary for him to concentrate his will on maintaining a balance between self-assertion and self-restraint. As far as man can

$$
\begin{aligned}
& 127 \text { Life, p. } 152 . \\
& 128 \text { Hixxley, p. } 440
\end{aligned}
$$


know the influences and the effects of a situation, he must adapt his will towards preventing and avolding suffering. In situations in which man cannot prevent or avoid suffering, he must adapt his will towards keeping pain to a minimum. Betterment becomes a dymamic process of continual precaution, balance, and consciousness of the contingencies of actions and decisions; an active process of working towards the best consummation possible.

With the persistence of the unforeseen which may arise from Nature In its unconsciousness and negligence of man and from people who do not act through loving-kindness and from social conventions and structures which are insensitive to the individual, weariness of conflict with adversity may make people reject their passions, desires, and aspirations. ${ }^{129}$ When the children died in Jude the Obscure, Sue Bridehead rejected all of her former ideas and aspirations to begin mortification of the flesh (Jude, p. 416). The necessity of constant vigilance and adaptation demands a great exertion of human will and a corresponding loss of settled ideas, philosophy, or religion which try to make the world comfortable for man. Man's experience shows that pain, sorrow, and wrong are realities. 130 It is not until man ceases to try to escape pain and sorrow for himself alone, a manifestation of excessive selfassertion, and begins to see himself in a now way, as a modifier of the conditions of man's existence, that man mas hope to abate suffering in

129 Samuel Johnson, The History of Rasselas: Prince of Abissinia, ed. Geoffrey Tillotson and Brian Jenkins (London: Oxford University Press, 1971), p. 127 .

130 Huxley, p. 71. 
the world. In that way, man would work to help all men escape pain and sorrow.

Indeed, when the characters in Hardy's novels who had a strong passion for life tried selfishly to escape pains and sorrows for themselves only, the results of their attempts were unsuccessful. Sergeant Troy increased rather than decreased suffering when he disappeared after Fanny Robin's death. Eustacia Vye brought sorrow to Clym and death to herself, Wildeve, and Mrs. Teobright trying to avoid the pain of confronting Mrs. Yeobright and later Clym. Angel Clare found fever and debilitation trying to escape and avoid the pain of Tess's past. Whenever characters attempted to protect themselves only from suffering, they brought additional suffering to themselves and left others in a morass.

It is not, then, a simple solution to man's suffering which Hardy proposed. It is a painful process which recognizes and confronts suffering, and the possibilities of additional suffering in order to advance faltering man a step or two at a time through his will. Even Jude Fawley recognized that his individual accomplishment was too bold a step in a world that evolves slowly. "Our ideas were fifty years too soon to be any good to us"(Jude, p. 484). Whether some of the early steps towands the evolution of a new Grace-global patriotism, the exchenge of international thought, and the salvation of the world-are possible "before the year 10,000 is of course what skeptics may doubt. $n^{\dagger 31}$ The outbreak of "monstrosities of human actions explicable 


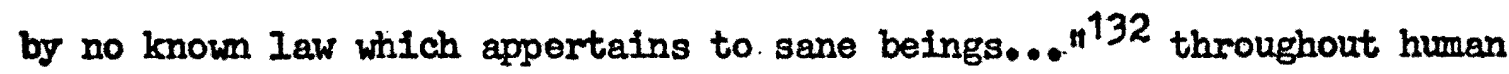
history is an indication of the "tendency to the reintroduction of the cosmic struggle into...the artificial fabric.... and destroys that peace which is the fundamental condition of the maintenance of the state of art against the state of nature." 133

132 Iife, p. 117.

133 fluxley, p. 21. 


\section{CHAPTER VI}

\section{CONCLUSION}

If human will seems to be not wholly effective in improving man's condition immediately, he does seen to have moments when he can act. These choices may seem insignificant in terms of the whole process and movement of Iife. They are still significant morally in human terms. Hardy does not seem to be arguing whether man Iives by free will or by necessity (for hin there was apparently some of both), rather the moral question of how man uses his cholces. Even if man has only a choice between two unfortunate possibilities, the choice he makes at that point is finally important morally because of its possible effect on subsequent situations. In Under the Greenwood Tree, Fancy Day had a choice between marrying either Dick Dewy or Parson Maybold. The reader is led to feel, by implication, that if she had chosen Maybold, a suitor more equal to her and her father's expectations, then the results of the marriage would have been disastrous. The choice was between incomplete fulfillment of expectations and suffering; both choices involved an unfortunate aspect, but one choice was implied to have been ethically better. Adaptability becomes important. Fixed ideas, ideals, philosophles, and religions will die because they cannot adapt. The surviral of man in the modern age will depend on adaptation through loving-kindness. To adapt properly means taking a full look at the Worst, even anticipating the worst circumstances and consequences, then responding 
to the circumstances to keep pain and suffering to a minimum, not only for oneself, but for others; an altruism of loving-kindness.

The process of adaptation is a process of will. To suspend emotional as well as intellectual judgment in difficult cases is not easy and can be quite painful. To give up ideas, ideals, philosophies, or religions which are comfortable, self-serving, or otherwise flattering in order to adapt may be quite painfur, at least psychically. The pain can develop, Hardy suggests, into the "coming Universal wish not to Iive." In an existence in which stasis is deadly, in which constant adaptation is required, and in which constant change leaves every man rootless, life may be tiring and debilitating. A man may decide that the need for constant adaptation is too exhausting and wish for the peace, rest, and stasis of utopian ideas and philosophies or, on a less Intellectual plane, simply his daily habits. Hardy had his utopian idea also, though but shortly entertained. ${ }^{134}$ At that point when utopianisms can no longer be entertained, existence may seem less attractive than death which, at least in Hardy's vision, is the only static state in the modern age.

The loss of fixed, transcendent ldeas is a basis for Hardy's sadness. Hardy's novels and other writings show his lament for the destruction of old relics, churches, and antiquities. The replacement of the old with the new in the modernization of the rural order to the industrial order is a sign of the permanent loss of static elements in

134 Iffe, p. 258. Briefly, Hardy's utopian idea was to organize society into groups based on temperament which, he felt, would give individual spontaneity and promise better chances for happlness than a curbed and uniform society. 
society and life. Hardy saw, at once, the need for change and adaptation, and the sadness of the loss of stasis. The changes are inevitable, oven desirable if toil, hardships, and suffering are to be alleviated. The romantic nature of the old postillians and other rural workers must not halt the alleviation of their suffering. 135 The changes can be deadly, however, if man does not adapt with loving-kindness. Without loving-kindness, man may destroy some of the rich variety of humanity which does not cause suffering, but without whlch progress in civilization may not be possible. $\$ 36$

"Grace" is the human will, evolving into instinct, to act through Ioving-kindness. Loving-kindness is not enough in itseIf. Grace Melbury felt Ioving-kindness for Giles Winterborne; and Giles for Grace. Their failure to act upon their feelings led to Giles' death and Grace's scourgings. There needs to be a balance between self-assertion and selfrestraint. The consciousness to know when either one motivation or the other is needed is an aspect of man's betterment towards the new "Grace." This consciousness comes through suffering, the Individual's and others'. Suffering can be, then, the basis for man's betterment.

The exploration of reality and the recognition of its. worst aspects, especially suffering, and the evolution of an intense consciousness of the sufferings of others through the network or tissue of mankind, give man a knowledge of suffering and its causes upon which he may act with loving-kindness. Suffering can give man the information

135 Notebooks, pp. 46-48, 61-62.

136 Bagehot, pp. 60-61. 
85

and the motivation he needs to adapt his will towards the Better. If man can evolve towards ameliorating the conditions of his existence in his relations with other men, the influence of his will may affect the Universal Will, of which man's will is a part, and bring the Universal WIII to consciousness and sympathy. If evolutionary meliorism extends beyond man to the Universe, then the Universe, too, could come into Grace, making existence Itself a state of Grace. The creative force might be reinstated as the new, beneficial Providence. Until that happens, if indeed it may before the exhaustion or the destruction of the world or man, man must exert his will to make his portion of the world as painless as possible. Men must will "to afford the greatest happiness to the units of human society. "137

137 Orel, p. 20. 
Abercrombie, Lascelles. Thomas Hardy: A Critical Study. London: Martin Secker, 1912.

Anderson, John D. "Hardy, First of Moderns." New York Times Book Review, May 28, 1922, p. 10.

Anon. "The Hardy Spirit." Times Literary Supplement, February 1, 1952, p. 93.

Arnold, Matthew. Poems. Vol. 1 of The Works of Matthow Arnold. Edition de Iuxe. 15 vols. London: Mackilian and Company, Itd., 1903.

Bagehot, Valter. Physics and Politics: Or Thoughts on the Aoplication of the Princioles of "Natural Selection" and "Inheritance" to Political Society. 1872; rpt. New York: Alfred A. Knopf, 1948.

- Literary Studies. Everyman's Iibrary. 2 vols. London: J. M. Dent and Sons, Ltd., and New York: E. P. Dutton and Company, 1911.

Bailey, J. O. "Hardy's 'Mephistophelian Visitants." PMA, 61 (1946), $1146-84$.

(1959), "Hardy's Vision of the Self." Studies in Philology, 56
.

- "Temperament as Motive in The Return of the Native." English Literature in Transition, 5 (1962), 21-29.

Baker, Ernest A. The History of the English Novel. 10 vols. 1938; rpt. New York: Barnes and Noble, Inc., 1950.

Baker, James R. "Thematic Ambiguity in The Mavor of Casterbridge." Twentieth Century Literature, 1 (1955), 13-16.

Bartlett, Phyllis. "Hardy's Shelley." Keats-Shelley Journal, 4 (1955), 15-29.

Fiction." "Seraph of Heaven:' A Shelleyan Dream in Hardy's Fiction." PliL, 70 (1955), 624-35.

Beach, Joseph Warren. The Technique of Thomas Hardy. 1922; rpt. New York: RusseII and Russell, 1966. 
Beebe, Maurice, Bonnie Culotta, and Erin Marcus, comps. "Criticism of Thomas Hardy: A Selected Checklist." Modern Fiction Studies, 6 $(1960), 258-79$.

Benvenuto, Richard. "The Returm of the Native as a Tragedy in Six Books." Wineteenth Century Fiction, 26 (1971), 83-93.

Benzing, Rosemary. "In Defense of 'Tess." Contemporary Review, 218 (1971), 202-04.

Blunden, Edmund Charles. Thomas Hardy. Iondon: MacMiIIan and Company, 1951.

Bohling, Beth. "Why Michael Henchard?" English Journal, 55 (1966), 203-04 and 207.

Boyd Emest Augustus. Iiterary Blasphemies. New York: Harper and Brothers Publishers, 1927.

Braybrook, Patrick. Philosophies in Modern Fiction. 1929; rpt. Freeport, New York: Books for Iibraries, Inc., 1965.

Brennecke, Ernest, Jr. The Iife of Thomas Hardy. New York: Greenberg, Publisher, Inc., $19 \overline{925}$.

Nind. 1926; rpt. New York: RusseII and Russe11, 1966 . Thomas $\frac{\text { Hardy's }}{\text { Noet's }}$

Brick, Allan. "Paradise and Consciousness in Hardy's Tess." Nineteenth Century Fiction, 17 (1962), 115-34.

Brogan, Howard O. "Visible Essences' in The Mayor of Casteroridge." ELH, $17(1950), 307-23$.

Brown, Douglas. Thomas Hardy. 2nd ed. Iondon: Iongmans, 1961.

Browning, Robert. The Poetical Works of Robert Browning. 1905; rpt. Iondon: Oxford University Press, 1946.

Burton, Richard. Masters of English NoveI: A Study of Principles and Personalities. Wew York: Henry Holt and Company, 1909.

Casagrande, Peter J. 'The Shifted 'Center of Altruism' in The Woodlanders: Thomas Hardy's Third 'Return of a Native.'" ELH, 38 $(1971), 104-25$.

Cecil, Lord David. Hardy, the Novelist: An Essay in Griticism. 1943; rpt. Iondon: Constable and Company, Itd., $19 \overline{54 .}$

Chambers, Robert. Vestires of the Natural History of Creation. 3 rd ed. London: John Churchili, 1845. 
Chapman, Edward Mortimer. English Literature and Religion: 1800-1900. Iondon: Constable and Company, 1910.

Chapman, Frank. "Hardy the Novelist." Scrutiny, 3 (1934), 22-38.

Chesterton, G. K. The Victorian Age in Iiterature. 1913; rpt. Notre Dame: University of Notre Dame Press, 1962.

Chew, Samuel C. Thomas Hardy, Poet and Novelist. Bryn Mawr, Penn.: Bryn Mawr College, 1921.

Coleman, Terry. "The Truth about Hardy." Sunday Times Color Supplement, July 2, 1967, pp. 22-27.

Cox, Reginald Gordon, ed. Thomas Hardy: The Critical Heritage. London: Routledge and Kegan Paul, 1970.

Cross, Wilbur Lucius. Development of the English Novel. London: MacMillan and Company, 1899.

Cunliffe, John William. English Literature During the Last Half Century. New York: Mackíizan and Company, 1919.

Dawin, Charles Robert. The Origin of the Species. Author's authorized ed. 2 vols. New York: D. Appleton and Company, 1873.

Davis, W. Eugene. "Tess of the Durbervilles: Some Ambiguities about a Pure Woman." Nineteenth Century Fiction, 22 (1968), 397-401.

Dawson, William James. Makers of English Fiction. New York: Fleming H. Revell Company, 1905.

Day, Martin S. History of English Literature 1837 to the Present. New York: Doubleday and Company, Inc., 1964.

Deen, Leonard W. "Heroism and Pathos in Hardy's The Return of the Native." Nineteenth Century Fiction, 15 (1960), 207-19.

DeLaura, David J. " 'The Ache of Modemism' in Hardy's Later Novels." ELH, 34 (1967), 380-99.

Dike, Donald A. "A Modern Oedipus: The Mayor of Casterbridge." Essays in Criticism, 2 (1952), 169-79.

Dobree, Bonamy. The Lamp and the Lute: Studies in Seven Authors. 2nd ed. Iondon: Frank Cass and Company, 1964.

Duerksen, Roland A. Shelleyan Ideas in Victorian Iiterature. The Hague: Mouton and Company, 1966 . 
Duffin, Henry Charles. Thomas Hardy: A Study of the Wessex Novels. 3rd ed. Manchester: The University Press, 1937.

Edwards, Duane. "Chance in Hardy's Fiction." The Midwest Quarterly, $11(1970), 427-41$.

Hiliott, Albert Pettigrew. Fatalism in the Works of Thomas Hardy. 1935; rpt. New York: Russell and Russell, $19 \overline{66}$.

Emett, V.J., Jr. Marriage in Hardy's Iater Novels." The Midwest Quarterly, 10 (1969), 331-48.

Evans, Robert. "The Other Eustacia." Novel, 1 (1968), 251-59.

Fayan, George Siemers, Jr. Mardy's The Woodlanders: Inwardness and Memory." Studies in English Litorature 1500-1900, 1 (1961), 81-100.

Firor, Ruth A. Folkways in Thomas Hardy. New York: A. S. Barnes and Company, Inc.; 1931 .

Fletcher, John Gould. "The Spirit of Thomas Hardy." Yale Review, 13 $(1924), 322-33$

Follett, Helen Thomas and Wilson Follett. Some Moderm Novelists: Appreciations and Estimates. 1918; rpt. Freeport, New York: Books for Iibraries, Inc., 1967.

Forster, E. M. Aspects of the Novel. New York: Harcourt, Brace and Company, 1927.

Friedman, Norman. "Point of View in Fiction: The Development of a Critical Concept." PMIA, 70 (1955), 1160-84.

Friedman, S. "Auden and Hardy." Notes and Queries, 13 (1966), 419.

Frye, Prosser Hall. Iiterary Reviews and Criticisms. New York: G. P. Putnam's Sons, 1908.

Goldberg, M. A. "Hardy's Double-Visioned Universe." Essays in Criticism, 7 (19.57), 374-82.

Gose, Elliott B., Jr. "Psychic Erolution: Darwinism and Initiation in Tess of the D!Urbervilles. "Nineteenth Gentury Fiction, 18 $(1963), \overline{261}-72$

Gregor, Ian. mardy's World." EIH, 38 (1971), 274-93.

Griffith, Philip Malone. The Image of the Trapped Animal in Hardy's Tess of the Divrbervilles." Tulane Studies in English, 13

(1963), 85-94. 
Grimsditch, Herbert Borthwick. Character and Environment in the Novels of Thomas Hardy. Iondon: H., F., and G. Witherby, 1925.

Hardy, Enma Lavinia. Some Recollections. Ed. Evelyn Hardy and Robert Gittings. London: Oxford University Press, 1961.

Hardy, Evelyn. Thomas Hardy: A Critical Biography. New York: St. Martin's Press, 1954. .

Hardy, Florence Enily. The Life of Thomas Hardy 1840-1928. 1928, 1930; rpt. 2 vols. in 1, New York: St. Martin's Press, 1962.

Hardy, Thomas. Under the Greenwood Tree or The Mellstock Quire: A Rural Painting of the Dutch School. Anniversary ed. New York: Harper and Brothers Publishers, 1920.

- Far from the Madding Crowd. Anniversary ed. New York: Harper and Brothers Publishers, 1920.

- The Return of the Native. Anniversary ed. New York: Harper and Brothers Publishers, 1920.

- The Life and Death of The Nayor of Casterbridge: $A$ Story of a Man of Character. Anniversary ed. New York: Harper and Brothers Publishers, 1920.

- The Woodlanders. Anniversary ed. New York: Harper and Brothers Publishers, 1920.

- Tess of the D'Urbervilies: A Pure Woman. Anniversary ed. New York: Harper and Brothers Publishers, 1920.

- Jude the Obscure. Anniversary ed. New York: Harper and Brothers Publishers, 1920. Company, 1958.

- Thomas Hardy's Notebooks. Ed. Bvelyn Hardy. New York: St. Martin's Press, 1955.

- Thomas Hardy's Personal Writings. Ed. Harold Orel. Lawrence, Kansas: University of Kansas Press, 1966.

Hassett, Michael E. "Compromised Romanticism in Jude the Obscure." Nineteenth Gentury Fiction, 25 (1971), 432-43.

Heilman; Robert B. "Hardy's 'Mayor' and the Problem of Intention." Criticism, 5 (1963), 199-213. 
Hei]man, Robert B. "Hardy's Sue Bridehead." Nineteenth Century Fletion, 20 (1966), 307-23.

Herbert, Iucille. "Hardy's Views in Tess of the D'Urbervilles." ELH, 37 (1970), 77-94.

Hind, Charles Lewis. Authors and I. London: John Lane Company, 1921.

Holland, Norman, Jr. "Jude the Obscure: Hardy's Symbolic Indictment of Christianity." Nineteenth Century Fiction, 9 (1954), 50-60.

Holloway, John. The Victorian Sage: Studies in Argument. 1953; rpt. Iondon: Archon Books, 1962.

- "Hardy's Major Fiction." From Jane Austen to Joseph Conrad: Essays Collected in Memory of James T. Hillhouse. Ed. Robert C. Rathbum and Martin Steinmann, Jr. Minneapolis: University of Minnesota Press, 1958. p. 812. - "Has Hardy Dated?" Spectator, December 17, 1965,

Hornback, Bert G. The Metaphor of Chance: Vision and Technique in the Works of Thomas Hardy. Athens, Ohio: Ohio University Press, 1971.

Hurley, Robert. "'Crumby' Tess." Notes and Queries, 12 (1965), 303.

Huss, Roy. "Social Change and Horal Decay in the Novels of Thomas Hardy." Dalhousie Review, 47 (1967), 28-44.

Hurrley, Thomas Henry. Evolution and Ethics and Other Essays. 1902; rpt. as vol. 9 of Collected Essays. 9 vols. New York: Creenwood Press, Publishers, 1968.

Hyde, William J. "Hardy's Response to the Critics of Jude." Victorian Newsletter, No. 19 (Spring, 1961), pp. 1-5.

the Obscure." "Wheoretic and Practical Unconventionality in Jude

James, William. Varieties of Religious Experience: A Study in Human Nature. 1902; rpt. New York: The Modern Library, 1936.

Johnson, Lionel. The Art of Thomas Hardy. New York: Dodd, Mead, 1895.

Johnson, Samuel. The History of Rasselas: Prince of Abissinia. Ed. Geoffrey Tillotson and Brian Jenkins. London: Oxford University Press, 1971. 
Karl, Frederick R. "The Mayor of Gasterbridge: A New Fiction Defined." Modern Fiction Studies, 6 (1960), 195-213.

Kiely, Robert. "Vision and Viewpoint in The Mayor of Casterbridge." Nineteenth Gentury Fiction, 23 (1968), $189-200$.

Lawrence, D. H. "Study of Thomas Hardy." Phoenix: The Posthumous Papers of D. H. Lawrence. Ed. Edward D. McDonald. New York: The Viking Press, 1936.

Iillard, Richard Gordon. "Irony in Hardy and Conrad." PMLA, 50 (1935), 316-22.

Macy, John. "The World of Thomas Hardy." The Book League Monthly, 1 (1928), 149-59.

Magnus, Laurie. Inglish Literature in the Nineteenth Gentury. New York: G. P. Putnam's Sons, 1909 .

Matchett, W. H. "The Woodlanders,' or Realism in Sheep's Clothing." Nineteenth Century Fiction, 9 (1955), 241-61.

McCann, Bleanor. "Blind Will or Blind Hero: Philosophy and Myth in Hardy's The Return of the Native." Criticism, 3 (1961), 140-57.

McCullen, J. T., Jr. "Henchard's Sale of Susan in The Mayor of Casterbridge." English Language Notes, 2 (1965), 217-18.

McDowall, Arthur Sydney. Thomas Hardy: A Critical Study. London: Faber and Faber, Itd., 1931.

McDowell, Frederick P. W. "In Defense of Arabella: A Note on Jude the Obscure." English Language Notes, 1 (1964), 274-80.

Meisel, Perry. Thomas Hardy: The Returm of the Repressed: A Study of the Major Fiction. New Haven: Yale University Press, 1972.

Mill, John Stuart. On Liberty. 1859; rpt. New York: Bobbs-Merrill Company, Inc., 1956.

- Three Essays on Religion: Nature, The Utility of Religion, and Theism. 4th ed. London: Longmans, Green, Reader, and Dyer, 1875.

Miller, Joseoh Hillis. "Recent Work on Hardy." Victorian Studies, 10

- The Form of Victorian Fiction: Thackery,

Dickens, Trollope, George Eliot, Meredith, and Hardy. Notre Dame: University of Notre Dame Press, 1968. 
Miller, Joseph Hillis. Thomas Hardy: Distance and Desire. Cambridge, Mass.: Harvard University Press, 1970.

Mordell, Albert. Notorious Literary Attacks. 1926; rpt. Freeport, New York: Books for Iibraries Press, 1969.

Morrell, Roy. Thomas Hardy: The Will and the Way. Kuala Lurpur: University of MaIaya Press, 1965.

Moynahan, Julian. The Mayor of Casterbridge and the Old Testament's First Book of Samuel: A Study of Some Iiterary Relationships." PMLA, 71 (1956), 118-30.

Newton, Wilizam. "Chance as Employed by Hardy and the Naturalists." Philological Quarterly, 30 (1951), 154-75.

The Oxford Dictionary of the Christian Ghurch. Ed. F. I. Cross. London: Oxford University Press, 1958.

Paris, Bermard J. "A Confusion of Many Standards: Conflicting Value Systens in Tess of the DiUrbervilies." Nineteenth Century Fiction, 24 (1969), 57-79.

Parker, T. H. I. "Grace." Baker's Dictionary of Theology. Ed. Everett F. Harrison, et al. Grand Rapids, Mich.: Baker Book House, 1960.

Paterson, John. "The Mayor of Casterbridge as Tragedy." Victorian Studies, $3(1959), 151-72$.

- "The 'Poetics' of The Return of the Native." Modern Fiction Studies, $6(1960), 21 \overline{4-22}$.

- Mardy, Faulkner, and the Prosaics of Tragedy." The Centennial Review, 5 (1961), 156-75.

Phelps, William Lyon. Essays on Modern Novelists. New York: The MacMilian Company, 1910.

Pilkington, Frederick. "Religion in Hardy's Novels." Contemporary Review, 188 (1955), 31-35.

Powys, John Cowper. Yisions and Revisions: A Book of Literary Devotions. Hew York: G. Arnold Shaw, 1915.

Powys, Ilewelgn. Thirteen Worthies. New York: American Library Service, 1923.

Purdy, Richard I. Thoraas Hardy: A Bibliographical Study. New York: Oxford University Press, 1954. 
Quililer-Couch, Arthur T. Adventures in Criticism. New York: G. P. Putnam's Sons, 1925.

Richards, Mary Caroline. "Thomas Hardy's Ironic rision." Nineteenth Century Fiction, Part I, 3 (1949), 265-79, and Part II, 4 (1949), 21-35.

Ruskin, John. "The Nature of the Gothic." The Stones of Venice. A new ed. 3 vols. London: Smith, Elder and Company, 1873.

Rutland, William R. Thomas Hardy: A Study of His Writings and their Background. 1938; rpt. New York: RusseII and RusseII, 1962.

Sankey, Benjamin. "Henchard and Faust." Inglish Ianguage Notes, 3 (1965), 123-25.

Schwartz, Barry N. "Jude the Obscure in the Age of Anxiety." Studies in English Literature 1500-1900, 10 (1970), 793-804.

Schweik, Robert C. Moral Perspective in Tess of the D'Urbervilles." College English, 24 (1962), 14-18.

- Theme, Character, and Perspective in Hardy's The Return of the Native." Philological Quarterly, 41 (1962), .757-67.

Casterbridge." "Character and Fate in Hardy's The Mayor of
Nineteenth Century Fiction, 21 (1966), $249-62$.

Scott-James, RoIfe Arnold. Lodernism and Romance. London: John Lane, 1908.

1951.

- Thomas Hardy. London: Longmans, Green,

Selby, Thomas Gunn. The Theology of Modern Fiction. London: Charles H. KelIy, 1897.

Sherman, Stuart Pratt. On Contemporary Literature. New York: Henry Holt and Company, 1917.

Sontag, Susan. Against Interpretation and Other Essays. New York: Farrar, Straus and Giroux, 1966.

Spencer, Herbert. First Principles. 6th ed. New York:'D. Appleton and Company, 1910.

Spivey, Ted R. "Thomas Hardy's Tragic Hero." Nineteenth Century Fiction, 9 (1954), 179-91. 
Starzyk, Laurence J. "The Coming Universal Wish Not to Live in Hardy's 'Modern' Novels." Nineteenth Century Fiction, 26 (1972), 419-35.

Steig, Michael. "Sue Bridehead." Novel, 1 (1968), 260-66.

Stephen, Leslie. Social Rights and Duties: Addresses to Ethical Societies. 2 vols. New York: Macilizlan and Company, 1896.

Stevenson, Iionel. "Hardy in Two Centuries." Yale Review, 60 (1970), $126-30$.

Swigg, Richard. Lawrence, Hardy, and American Iiterature. London: Oxford University Press, 1972.

Thompson, Edward Raymond. Portraits of the Nineties. Iondon: T. F. Unwin, Itd., 1921.

Van Doren, Carl and Mark Van Doren. American and British Literature Since 1890. London: The Century Company, 1925.

Wagenknecht, Edward. "'Pessimism' in Hardy and Conrad." College English, 3 (1942), 546-54.

Weatherby, H. I. "Old-Fashioned Gods: Eliot on Lawrence and Hardy." Sewanee Review, 75 (1967), 301-16.

Weber, Carl Jefferson. "Care and Carelessness in Hardy." Modern Language Notes, 50 (1935), 41-43.

- Hardy of Wessex: His Life and Literary Career. 1940; rpt. Hamden, Conn.: Archon Books, 1962 .

Webster, Harvey Curtis. On a Darkling Plain: The Art and Thought of Thomas Hardy. Chicago: University of Chicago Press, 1947.

Wing, George Douglas. Hardy. Edinburgh: Oliver and Boyd, 1963.

Wordsworth, William. "Resolution and Independence." The Poetical Works of Wordsworth. Ed. Thomas Hutchinson and Ernest De Selincourt. Iondon: Oxford University Press, 1950.

Yuill, W. E. "Character is Fate: A Note on Thomas Hardy, George Eliot, and Novalis." Modern Language Review, 57 (1962), 401-02.

Zabel, Morton Dauven. "Hardy in Defense of His Art: The Aesthetic of Incongruity." The Southerm Review, 6 (1940), 125-49. 